\title{
El rescate de concesión de obra pública. Apuntes al rescate del túnel de Sóller
}

Mercedes Lafuente Benaches

DOI: https://doi.org/10.47623/ivap-rvap.110.2018.1.11

\begin{abstract}
Sumario. I. Introducción.-II. El rescate de concesiones administrativas sobre infraestructuras viarias. 1. La desfiguración reciente de la institución. 2. La incidencia de la normativa europea en materia de concesiones y la polémica sobre si cabe o no rescatar. - III. El rescate de la concesión del túnel de peaje de Sóller. 1. Sus elementos definidores. 1.1. Concesión de obra pública. 1.2. Túnel de peaje. 2. Antecedentes. 3. Pronunciamientos emitidos. 3.1. La aprobación de la propuesta de rescate. 3.2. El Dictamen del Consejo Consultivo de las Islas Baleares. 3.3. La resolución sobre el rescate. 3.4. El Auto del Juzgado de lo Contencioso-Administrativo de suspensión del rescate. 3.5. El Auto del Tribunal Superior de Justicia de las Islas Baleares que deja sin efecto la medida cautelar de suspensión del rescate. 4. Problemas jurídicos que suscita. 4.1. La normativa aplicable. 4.2. En especial. 4.2.1. La competencia para el rescate. 4.2.2. La instrucción del procedimiento. 4.2.3. La motivación de la resolución que legitima el rescate. 4.2.4. La valoración económica del rescate. a. La necesidad de una mayor seguridad jurídica en los criterios utilizados para concretar los elementos indemnizables. b. Del periodo temporal sobre el que versa la indemnización por rescate. c. De la normativa aplicable para calcular el importe de la indemnización por rescate.-IV. Redefiniendo el rescate. Propuestas de mejora.
\end{abstract}

\section{Introducción}

El rescate alude a una forma de resolución unilateral de ciertos negocios jurídicos de naturaleza principalmente bilateral (1), por los que se había concedido a un particular el disfrute, la explotación o la gestión del

(1) Para el rescate de las autorizaciones o concesiones demaniales de naturaleza unilateral, véase a MESTRE DELGADO. JF. "La extinción de las autorizaciones y concesiones demaniales» en Comentarios a la Ley 33/2003, del Patrimonio de las Administraciones Públicas. Coord. por M. CHINCHILLA MARÍN.C., 2004, págs. 491-520. 
dominio público, la obra pública o el servicio público por parte de la $\mathrm{Ad}$ ministración pública (2).

La doctrina se ha ocupado del rescate marcando las diferencias con otras formas de resolución, pero sin abordar el análisis de la institución con la profundidad que exige un trabajo laborioso y complejo, donde poco ayuda la falta de concreción de criterios indubitados en la normativa a la hora de clarificar cuestiones nucleares en torno a la misma como, por ejemplo, la delimitación de la genérica causa de interés público que justifica el rescate y los efectos (jurídicos y económicos) que genera. Además, la jurisprudencia escasa, casuística y repetitiva en los supuestos contemplados, tampoco proporciona criterios sólidos a la hora de perfilar la institución. Quizás, por ello, durante mucho tiempo ha sido un tema ausente o solo, parcialmente, presente en los trabajos doctrinales que no ha suscitado excesivo interés, la «niña fea» de las causas de resolución.

Existe un resurgimiento del interés por la potestad administrativa de rescate donde se polemiza sobre la conveniencia de mantenerla o de redefinirla. La causa de interés público que debiera justificar su ejercicio encubre una variedad de supuestos ajenos a la institución, ya que se acude

(2) La doctrina está dividida sobre si el rescate es una potestad administrativa (también se discute si la potestad puede ser implícita o ha de ser expresa) o si tiene naturaleza contractual. En la doctrina española, a favor de su naturaleza de potestad con distintos matices, ALBI. F., Tratado de los modos de gestión de las Corporaciones locales, Ed. Aguilar, Madrid, 1960, pág. 657; BERMEJO VERA. J. "La nacionalización ferroviaria de 1941 ", en Revista de administración pública, n. ${ }^{\circ} 72,1973$, págs. 73-128 y ÁLVAREZ GENDÍN. S., Tratado general de Derecho administrativo," Barcelona, 1958, T. I, pág. 466; GARRIDO FALLA. F., Tratado de Derecho administrativo, Madrid, T. II, 4.ed., Madrid,

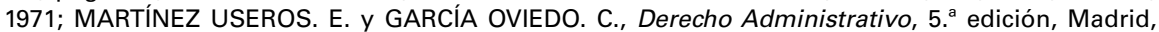
1955, T. I, págs. 307-308; MESTRE DELGADO. JF. (Op. cit., pág. 507) y PONCE SOLÉ. J. "Remunicipalización y privatización de los servicios públicos y derecho a una buena administración. Análisis teórico y jurisprudencial del rescate de concesiones," en Cuadernos de Derecho local, n. ${ }^{\circ} 40,2016$, págs. 68-108; BLANQUER CRIADO. D., La concesión de servicio público, Tirant lo Blanch, Valencia, 2012, pág. 1377). La doctrina francesa admite el rescate- potestad y el rescate contractual. MODERNE. F. "Le rachat des concessions», en Colléctivités Locales, t. III, París, 1985, pág. 3292 y ss. citado por CASSAGNE en El Contrato Administrativo, Abeledo Perrot, Buenos Aires, 1999 pág. 99. JEZE. G. Principios Generales del Derecho Administrativo, Depalma, Buenos Aires, 1950, t. IV, págs. 244-249 y t.VI, pág. 372 y ss. En la doctrina argentina, discuten si el rescate puede ser contractual y legal y si la potestad de rescate ha de ser expresa o si puede estar implícita en los poderes de la Administración. CASSAGNE, El Contrato Administrativo, Abeledo Perrot, Buenos Aires, 1999 pág. 94 y ss.) admite ambas y descarta el rescate "como poder implícito no previsto en el contrato ni en la ley" a diferencia de MARIENHOFF, Tratado de Derecho Administrativo, Abeledo Perrot, Buenos Aires, 1966, t. III, pág. 578) y DROMI, Derecho Administrativo, Astrea, Buenos Aires, 1992, t. 1, pág. 429) que si lo admite. Y CAJARVILLE, "Extinción de los contratos de la Administración," en Contratación Administrativa (A.A.V.V), F.C.U., 1988, pág. 121) matiza que los poderes exorbitantes en materia de contratación administrativa derivados de las normas que los confieren (una ley o un contrato) o del principio de los poderes implícitos, no puede ser un postulado a priori del cual deducir poderes sino una comprobación inductiva a posteriori. Más exigente parece la postura de VILLARRUEL. S., "El rescate en los contratos administrativos" en Tratado general de los Contratos públicos (dirigido por CASSAGNE), La Ley, Buenos Aires, 2013, t. III, pág. 141 y ss.) al señalar la conveniencia de que sea la Ley la que determine el rescate en cada caso particular. 
a rescatar para sustituir al concesionario al margen de todo procedimiento, o como resultado de los cambios de orientación política de quienes gobiernan, avivando la polémica de si constituye otro medio de corrupción. Los cambios normativos que concluyen con la reciente Ley 9/2017, de 8 de noviembre, sobre Contratos del Sector Público constituyen un paso más en la evolución sobre el rescate que también merece una valoración.

El controvertido rescate de la concesión del túnel de Sóller, todavía sub júdice, nos sirve de contexto para profundizar en la rica problemática que el supuesto ofrece y para mostrar los problemas y las debilidades de la institución, a través de su análisis(3).

\section{El rescate de concesiones administrativas sobre infraestructuras viarias}

Resulta incuestionable la trascendencia de las infraestructuras viarias como elemento dinamizador de la economía, como condición para el ejercicio de derechos básicos (el derecho al trabajo o a la libertad de movimiento) y como elemento clave de la planificación del territorio y de la cohesión social.

Por infraestructuras viales entendemos todo el conjunto de elementos que posibilita el desplazamiento de vehículos en forma confortable y segura. Lo son todo tipo de carreteras, autopistas, vías y caminos así como los puentes o túneles con la amplitud dada por el artículo 157 de la Ley 13/1996, de 30 de diciembre, de Medidas Fiscales, Administrativas y del Orden Social al ámbito objetivo de la Ley 8/1972, de 10 de mayo, sobre construcción, conservación y explotación de las Autopistas en régimen de concesión (4).

Constituyen obras públicas que se asientan sobre bienes de dominio y uso público, de titularidad administrativa (5). La planificación, la financiación, la construcción, el mantenimiento y la explotación entran dentro del ámbito de competencias de la Administración pública.

(3) La Administración Autónoma Balear, alguno de los Ayuntamientos implicados y ciertas instancias judiciales no han dudado en facilitarnos la documentación analizada en una clara demostración de transparencia.

(4) También el artículo 17. 1. a. ii) del Reglamento (UE) $n{ }^{\circ} 1315 / 2013$ del Parlamento Europeo y del Consejo, de 11 de diciembre de 2013, sobre las Orientaciones de la Unión para el desarrollo de la Red Transeuropea de Transporte, y por el que se deroga la Decisión n. ${ }^{\circ}$ 661/2010/UE Texto pertinente a efectos del EEE.

(5) Por ejemplo, en materia de concesiones de autopistas, la Ley 8/1972 establece la atribución de competencias administrativas, determina el alcance de las prestaciones en favor de los administrados y declara que el servicio constituye una actividad propia del Estado. 
Cuando la construcción y explotación de la infraestructura se conceden a un particular estamos en presencia de una concesión de obras. (6)Esta opción de gestión posibilita la participación público-privada al amparo de los artículos 220. $1 .^{\circ}$ de la Ley 13/2003, de 23 de mayo, reguladora del Contrato de concesión de obras públicas y 14 de la Ley 9/2017, de 8 de noviembre, de Contratos del Sector Público.

Este mecanismo de colaboración ha suscitado adeptos y detractores en paralelo a los objetivos políticos y económicos, perseguidos por la Administración, en cada periodo histórico (7). Después de una época de tendencia privatizadora, justificada en la ineficiencia de la gestión pública y en razones de carácter económico que perseguían ampliar las inversiones en infraestructuras a través de fórmulas de asociación público-privadas, en los últimos tiempos se aprecia un fenómeno opuesto a la externalización y a favor de la reinternalización en la Administración de cometidos previamente entregados a los particulares que se justifica en la mala gestión de los particulares. La recuperación por la Administración pública de la actividad prestada y gestionada por el particular, incide en la comunidad al asumir los costes económicos de esta transformación (8).

(6) ARIÑO ORTIZ. G., "Contrato de Obra, Concesión de Obra, Concesión de Servicio Público: ¿son técnicas intercambiables?», en Revista de derecho Administrativo, Circulo de Derecho administrativo n. ${ }^{\circ}$, 2009, pág. 12 y ss.) estima que empieza siendo de obra pública para terminar siendo de servicio público en la medida que «la construcción de la obra es un simple presupuesto de lo que en realidad es el objeto del contrato, que consiste en su explotación, porque aquí es donde se encuentra la finalidad de interés público o, si se quiere, la "necesidad para los fines del servicio público" de que nos habla el artículo $13 .^{\circ}$ delTRLCA.»

(7) Simplificando existen dos modelos de financiación, privado y público. El modelo de financiación privado no emplea ayudas o garantías estatales y ni grava el presupuesto de la Administración pública ni repercute en el déficit público. La figura tradicional de este sistema es la concesión de obra pública, sin modalidades de ayudas públicas, lo que es desmentido en la realidad pues durante la fase de ejecución de la obra y sobre todo durante la explotación la Administración sale en su ayuda a través de modalidades varias: prórroga del plazo, reequilibrio, peajes en la sombra.... En el modelo de financiación público, el contribuyente termina soportando el costo de la inversión al utilizarse las partidas presupuestarias de las diferentes Administraciones Públicas como instrumento de financiación de la infraestructura, bien sea directamente con cargo a la partida de inversiones reales, o bien con cargo a transferencias corrientes (subvenciones) como inversiones financieras. Un análisis detallado en VASSALLO MAGRO. J.M, "Modelos de financiación de infraestructura» e IZOUIERDO DE BARTOLOMÉ, R. «Infraestructura pública y participación privada: conceptos y experiencias en América y España," publicaciones@caf.com, 2010.

(8) Una valoración prudente de los pros y contras del fenómeno remunicipalizador en ESTEVE PARDO. J., "Movimiento remunicipalizador. Experiencias y expectativas» en El Cronista de Estado Social y Democrático de Derecho n. ${ }^{\circ}$ 69, lustel, 2017, págs. 4-11). Este autor afirma cómo algunos de los logros destacados de estas remunicipalizaciones necesitan ser calibrados en todos sus efectos pues muchas veces acaban gravando, tal vez más, a los ciudadanos en su condición de contribuyentes por mucho que experimenten un alivio en su condición de usuarios de un servicio. También DOMíNGUEZ LUIS. J.A. («Equilibrio económico versus riesgo imprevisible en la concesión de obras públicas: El supuesto de las autopistas de peaje», Revista Aranzadi Doctrinal n. ${ }^{\circ} 8,2015$, págs. 113-161), concluye que el coste definitivo de una infraestructura pública inviable lo asumen todos los ciudadanos, vía presupuesto público. 
La concesión de obras, aunque aceptada y priorizada por la legislación como modelo de gestión (9), viene cuestionándose por los malos resultados de muchas de las concesiones vigentes propiciándose la vuelta al modelo de gestión directa, y recuperándose la potestad administrativa de rescate como técnica para materializar ese cambio.

Entre las contrariedades o efectos indeseados de la potestad de rescate, destacamos:

\section{La desfiguración reciente de la institución}

La potestad de rescate no siempre se utiliza de forma precisa y se ha convertido en una modalidad de resolución de la concesión de obras y de servicios que encubre, a menudo, situaciones ajenas a las que justifican su lícito ejercicio con el denominador común de poner fin a la relación, más allá de la recuperación por la Administración de la actividad desarrollada para una mejor gestión y de la existencia de un verdadero interés público sobrevenido.

Se acude al rescate de la actividad, con falta de tecnicismo y en un sentido más próximo a su acepción vulgar de "salvación o recuperación», para evitar males mayores en caso de continuidad. Un ejemplo reciente lo encontramos en el rescate de las concesionarias de autopistas (10) que tiene origen en un inadecuado planteamiento de la vida de las concesiones con quiebra de las concesionarias ante los resultados económicos negativos acumulados, fruto de una infravaloración del coste de las expropiaciones(11), de un incorrecto cálculo de los costes de construcción, al ignorar partidas tan significativas como los posibles perjuicios medioambientales, y de previsiones excesivamente optimistas de un tráfico potencial, muy inferior a la realidad.

Para continuar con el servicio y evitar el grave problema del cierre de las vías al tráfico, la Administración pública ha asumido el coste de la quiebra de nueve autopistas de peaje que oscila entre los 2000 y $5500 \mathrm{mi}-$ Ilones de euros. Las autopistas revertirán a la Administración y será la So-

(9) Así lo manifiesta VILLAR ROJAS, F. J., «Principios de sostenibilidad y estabilidad presupuestaria en la gestión de los servicios públicos locales», en El Cronista del Estado Social y Democrático de Derecho, n. ${ }^{\circ}$ 58-59, 2016, pág. 106).

(10) Sobre esta cuestión, RIDAO MARTÍN. J. y GARCÍA MARTíNEZ. A. "La precaria viabilidad de determinadas concesiones de autopistas de peaje en España. Lecciones estructurales para el modelo de colaboración público-privada y una propuesta de solución coyuntural", en Revista Andaluza de Administración Pública n. ${ }^{\circ} 87,2013$, págs. 95-135.

(11) Véase a ALBALATE. D., BEL.G. y BEL-PIÑANA. P., «Tropezando dos veces con la misma piedra: quiebra de autopistas de peaje y costes para contribuyentes y usuarios, en Revista de Economía Aplicada n. ${ }^{\circ} 67$ (vol. XXIII), 2015, págs. 131 a 152). 
ciedad Estatal de Infraestructuras Terrestres (Seittsa), de titularidad pública, quien asuma su gestión y preparare su relicitación para que vuelvan a manos privadas a finales de 2018 ya que no se pretende renacionalizarlas sino volver a ponerlas en el mercado(12). Claro ejemplo de que no estamos ante un genuino rescate, pese a su calificación como tal (13) porque la reinternalizacion de la gestión de las autopistas es consecuencia legal de la liquidación judicial de las concesionarias (14) y obliga a la Administración pública a asumir la responsabilidad patrimonial como titular de las infraestructuras.

Esta confusión terminológica nos adentra en otro tema, no siempre bien delimitado e importante, como es separar el montante de la indemnización debida al concesionario como consecuencia del ejercicio de la potestad de rescate o por responsabilidad patrimonial, dado que se utilizan criterios distintos para su cálculo. En el caso del rescate, se busca dejar completamente indemne a un concesionario que ha sido un buen gestor y por ello debe indemnizársele por las inversiones no rentabilizadas y los beneficios no obtenidos: valor de las expropiaciones, reducción del plazo inicial respecto a las obras y bienes no amortizados, por el lucro cesante y otros daños y perjuicios demostrables. En el supuesto de responsabilidad patrimonial, el importe final es el resultado de un cruce de indemnizaciones que se compensan: la Administración indemniza al concesionario por el valor de la concesión que pasa a gestionar para evitar que, con esta asunción, pueda derivarse algún tipo de enriquecimiento injusto para ella. El concesionario, en cambio, indemniza por los daños y perjuicios irrogados a la Administración al tener que gestionar la concesión, pudiendo serle incautada la fianza según la interpretación que merezca el supuesto(15).

(12) Resolución de 16 de agosto de 2017, de la Secretaría General Técnica, por la que se publica el Convenio de gestión directa con la Sociedad Estatal de Infraestructuras del Transporte Terrestre, $\mathrm{SME}, \mathrm{SA}$, por el que se regula la gestión de la explotación y la preparación de la licitación de Autopistas de titularidad estatal (BOE 25 de agosto de 2017).

(13) En los medios periodísticos digitales el término "rescate» alude a la situación concursal de las concesionarias. Véase http://www.elmundo.es/economia17/10/2017/ donde se indica que el Gobierno presupuesta 2.000 millones para rescatar las autopistas en 2018. También http://www.publico.es/ economia/ 17/10/2017 y http://www.elperiodico.com/ 16/11/2017/ en el que se reconoce que el rescate de las autopistas es una historia que no acaba.

(14) Véase los artículos 211 y 280 de la Ley 9/2017, de 8 de noviembre, de Contratos del Sector Público, por la que se transponen al Ordenamiento jurídico español las Directivas del Parlamento Europeo y del Consejo 2014/23/UE y 2014/24/UE, de 26 de febrero de 2014.

(15) Existe la posibilidad de considerar la quiebra como un supuesto imputable o no, al concesionario. La incautación de la fianza es un instrumento de penalización del incumplimiento culpable y voluntario; culpabilidad y voluntariedad que no siempre existen en todos los casos de quiebra. Así se ve en la sentencia de 5 de febrero de 2014, dictada por el Juzgado de lo Contencioso administrativo n. ${ }^{\circ} 2$ de Oviedo y ratificada por el Tribunal Superior de Justicia (Sala de lo Contencioso de Oviedo) en sentencia de 15 de junio de 2015, donde la ruinosa situación de la concesionaria no se califica de in- 
El valor a indemnizar, representado por la concesión, se calcula de forma distinta según cuál sea la legislación aplicable y la previsión de la transitoriedad en ella contenida(16). Con la normativa anterior a la Ley 40/2015, de 1 de octubre, la Administración debía indemnizar al concesionario por las inversiones realizadas según su grado de amortización, sin perjuicio de la indemnización debida por el concesionario a la Administración por los daños y perjuicios causados que reducirá el montante total de la indemnización a satisfacer(17). Esta indemnización a favor de la Administración tiene su origen en la resolución del contrato y determina el inicio del procedimiento para poder exigirla. En cambio, con la normativa posterior a la Ley 40/2015, de 1 de octubre, el cálculo del valor de la concesión no atiende al criterio la amortización de las inversiones realizadas sino a uno objetivo, determinado por el importe obtenido al ser nuevamente licitada, sin perjuicio de la posible indemnización de concesionario a favor de la Administración por daños y perjuicios que pasa a practicarse en un mismo procedimiento(18). La Ley 9/2017, de 8 de noviembre, de Contratos del Sector Público mantiene este valor objetivo pese a haber introducido algunos cambios en los criterios para cuantificar su importe final (19).

cumplimiento a efectos de renuncia del concesionario, sin exigirle la perdida de la fianza. También los trabajos de BOCANEGRA SIERRA, R. "La renuncia a las concesiones de obra como solución equilibrada en los supuestos de ruptura del equilibrio económico del contrato", en Memorial para la reforma del Estado: Estudios en homenaje al Profesor Santiago Muñoz Machado, coord. por José María Baño León, Vol. 3, 2016 (Tomo III), pág. 2580 y TORRE DE SILVAY LÓPEZ DE LETONA. J., "La indemnización de daños y perjuicios en los expedientes de resolución de concesiones administrativas: a propósito de los ingresos tributarios dejados de percibir» en Problemas prácticos y actualidad del Derecho Administrativo, Anuario 2015, Civitas págs. 19-45. Lo decisivo será distinguir entre el incumplimiento culpable y la imputabilidad de la causa por la que se resuelve el contrato, para determinar si procede o no la incautación de la fianza dependiendo de que el resultado de quiebra sea o no culpable.

(16) Resulta polémico decidir si la actual regulación es o no de aplicación a las concesiones adjudicadas con anterioridad a la entrada en vigor del artículo 271 bis ya que la Disposición Transitoria $4 .^{a}$ de la Ley 40/2015 que lo introduce dispone que sólo será de aplicación a los expedientes de contratación iniciados con posterioridad a la entrada en vigor de la misma, lo que dejaría al margen a las quiebras de las actuales concesionarias de autopistas. En contra BOCANEGRA SIERRA, R. (Op. cit., pág. 2580) y CAMPO. A., "Ley 40/2015, de 1 de octubre, de régimen jurídico del sector público. $\mathrm{E}$ nuevo régimen de la Responsabilidad Patrimonial de la Administración (RPA) y su impacto en esquemas de project finance de concesiones de obras públicas," Newsletter noviembre 2015, pág. 3; a favor CALATAYUD PRATS. I., "Riesgo y efectos de la resolución por incumplimiento del contratista de las concesiones de obra y servicio público: la liquidación del contrato (RPA) y la indemnización de daños y perjuicios», en Revista General de Derecho Administrativo n. ‥ 44, 2017.

(17) Artículo 271. 4 de la Ley 9/2017, de 8 de noviembre, de Contratos del Sector Público.

(18) Así lo mantiene CALATAYUD PRATS. I. (Op. cit. pág. 27) considerando que es una de las razones de la reforma introducida y que se canaliza a través de la técnica del «reemplazo.»

(19) En el supuesto de resolución por causa imputable a la Administración, además del importe de las inversiones realizadas descontadas las amortizaciones según un criterio de amortización lineal (no de "demanda o utilización»), la concesionaria tiene derecho a reclamar el lucro cesante, con unas nuevas reglas de cálculo de este lucro cesante y tomando como tasa de descuento el coste de capital medio ponderado correspondiente a las últimas cuentas anuales del concesionario, así como el daño emergente de las obras e instalaciones que no reviertan a la Administración (artículo 280). 
Generalmente, la indemnización por el rescate será más ventajosa para el concesionario que la que pudiera corresponderle por responsabilidad patrimonial, otra razón más para no incurrir en la confusión existente a la hora de calificar los distintos supuestos.

\section{La incidencia de la normativa europea en materia de concesiones y la polémica sobre si cabe o no rescatar}

La Directiva 2014/24/UE, de 26 de febrero de 2014 del Parlamento Europeo y del Consejo, relativa a la adjudicación de contratos de concesión, exigía su trasposición a nuestro Ordenamiento interno lo que se ha realizado con la Ley 9/2017, de 8 de noviembre, de Contratos del Sector público.

El hecho de que la Directiva no mencione el rescate como forma de resolución de la concesión (no figura entre las causas enunciadas en el artículo 44) ha sido interpretado de manera diversa. Un sector(20) lo interpreta como el fin de la institución en su consideración originaria de poder exorbitante, reconduciendo su potencial ejercicio a la potestad expropiatoria(21). Quienes justifican esta toma de posición alegan como razones la seguridad jurídica y el respeto al principio pacta sunt servanda y priorizan la igualdad de trato, la eficiencia y la integridad en la gestión de los fondos públicos sobre el interés público, que ya no es título jurídico suficiente para ejercer por sí solo potestades sobre un contrato en ejecución, debiendo prevalecer la seguridad del concesionario asentada sobre el principio de confianza legítima.

Otro sector(22) entiende que el Ordenamiento Comunitario respeta la libertad de elección de la forma de gestión de los servicios públicos por parte de los Estados miembros y que la mencionada Directiva, pese a no contemplar el rescate como forma de extinción, tampoco lo prohíbe. A su juicio, será la normativa que trasponga la Directiva al Ordenamiento interno quien que tenga la última palabra (23).

(20) Sobre esta cuestión GIMENO FELIU. J.M., SALA SÁNCHEZ. P. y QUINTERO OLIVARES. G., Público y privado. El interés público y su satisfacción con la colaboración público- privada. Fundamento, equilibrios y seguridad jurídica, Cámara de Comercio de Barcelona, Barcelona, 2017 y GIMENO FELIU. J. M., "Remunicipalización de servicios locales y Derecho comunitario» en El Cronista del Estado Social y Democrático de Derecho, n. ${ }^{\circ}$ 58-59, 2016, págs. 50-71.

(21) GARCÍA GÓMEZ DE MERCADO. F., "Contratos y concesiones de Obras: La Ley 13/2003 reguladora del contrato de concesión de obras públicas", en Revista Jurídica de la Comunidad de Madrid, n. $\left.{ }^{\circ} 16,2003\right)$ la califica de expropiación virtual porque, a diferencia de las expropiaciones propiamente dichas, no se siguen los procedimientos establecidos en la legislación de expropiación forzosa.

(22) PONCE SOLÉ. J. (Op. cit, pág. 68 y ss.).

(23) TORNOS MÁS. J., "La remunicipalización de los servicios públicos locales. Algunas precisiones conceptuales", en El Cronista del Estado Social y Democrático de Derecho, n. ${ }^{\circ}$ 58-59, lustel, 2016) considera que el poder adjudicador, según la nueva Directiva, parece perder la posibilidad de modi- 
La Ley 9/2017, de 8 de noviembre, de Contratos del Sector Público admite el rescate en los artículos 279 c) y 294 c). En el contrato de concesión de obras, el rescate será «la declaración unilateral del órgano contratante, discrecionalmente adoptada, por la que dé por terminada la concesión, no obstante la buena gestión de su titular" y en el contrato de concesión de servicios, la Administración podrá acordar el rescate del servicio para gestionarlo directamente "por razones de interés público». La potestad de rescate se mantiene si bien su ejercicio, además de la originaria razón de interés público, requerirá la acreditación de que ese interés público determina un cambio de gestión por lo que, únicamente, será legal si resulta ser una forma de gestión más eficaz y eficiente que la concesión. Rescatar será posible solo cuando las circunstancias de interés público impongan un cambio al modelo de gestión (directa) por resultar más eficaz y eficiente que el modelo de gestión anterior. Ello determina la imposibilidad de ejercitar la potestad de rescate con otras finalidades y excluye, muy especialmente, los rescates meramente ideológicos o políticos (24).

\section{El rescate de la concesión del túnel de peaje de Sóller}

Entre las infraestructuras viarias susceptibles de rescate están los túneles de peaje (25). Desde los más remotos tiempos pagar para pasar por una vía (26) ha sido desaprobado socialmente. Existe la convicción de que los bienes por donde discurren las infraestructuras viarias son de dominio público y que su destino natural es la utilización por la generalidad de forma gratuita, porque pagar para usar la vía se opone a la «libertad de ir

\footnotetext{
ficar la forma de gestión de un contrato en vigor por razones de oportunidad, esto es, en el ejercicio de la prerrogativa del rescate concesional. Así se deduce del artículo 44 de la Directiva 2014/23 aunque, en su opinión, habrá que esperar a la trasposición la Directiva para ver si ello se confirma.

(24) En este sentido, GIMENO FELIU. J.M., CAAMAÑO DOMÍNGUEZ. F., QUINTERO OLIVARES. G. y SALA SÁNCHEZ. P., Servicios públicos e ideología: El interés general en juego, Profit Editorial, 2017; COTS I VALVERDE. R., FEIJÓO REY. MJ., QUINTERO OLIVARES. G., y SALA SÁNCHEZ. P., La mejor gestión de los servicios municipales en favor de los ciudadanos y no de las ideologías. El interés general y la excelencia en los servicios públicos, Ed. Almuzara, Economía y Empresa, 2017; AGUILAR VALDEZ, O.R., "Caducidad, Rescisión y Rescate de concesiones en materia de infraestructura y servicios públicos", en la obra colectiva Servicio Público y Policía, Director CASSAGNE, J.C., El Derecho, 2006, pág. 153 y ss.) reconoce que el interés público tiende a confundirse -en ocasiones - con los cambios de orientación política, por lo que el rescate puede ser utilizado como medio de adecuación de la concesión a los vaivenes políticos, convirtiéndose de ese modo en un posible instrumento de corrupción.
}

(25) Un antecedente de rescate de túnel de peaje en nuestro país lo encontramos en 2016 con el túnel del AVE a Francia, donde el Gobierno asumió los 557 millones de deuda que había dejado ACS y su socio.

(26) Su más remoto origen (romano) se encuentra en los portazgos. Sobre esta cuestión GARCíA ORTEGA. P. Las concesiones administrativas de carreteras en el Ordenamiento jurídico español, Ministerio de Obras públicas y Urbanismo, 1978. 
y venir» (27). Esta creencia queda desmentida cuando el legislador, en la normativa comunitaria e interna, contempla los peajes como una opción al uso de las vías de comunicación (28).

La imposición de un peaje sólo podría ser combatido legalmente en el caso de ser discriminatorio para administrados que se encuentran en idéntica situación o cuando su finalidad sea impedir, injustificadamente, el tránsito.

\section{Sus elementos definidores}

La infraestructura relativa a la construcción de un túnel constituye una obra pública que, entre otras modalidades, puede ser financiada a través de un peaje. Este peaje podrá provenir de la Administración(29) o de los usuarios que la utilicen o de ambos.

\subsection{CONCESIÓN DE OBRA PÚBLICA}

Un túnel es una obra subterránea de carácter lineal que comunica dos puntos con la finalidad de dar paso al tráfico de personas y mercancías.

(27) Véase DUCROCO. T. "Ley del 30 de Julio 1880 sobre el rescate de las concesiones de puentes de peaje» en THORIN. E, Curso de Derecho Administrativo, 1881, París, T. II, 6. edición, págs. 128130; DE RUS. G. ROMERO. M. y TRUJILLO. L., Participación privada en la construcción y explotación de carreteras de peaje, Fundación Fondo para la Investigación económica y social, Universidad de Las Palmas de Gran Canaria, 2000, pág. 3) señalan que en España es muy general la percepción de que la carretera es un bien de uso libre que debe proveer el Estado.

(28) A nivel Comunitario, la Directiva 1999/62/CE del Parlamento Europeo y del Consejo, de 17 de junio de 1999, relativa a la aplicación de gravámenes a los vehículos pesados de transporte de mercancías por la utilización de determinadas infraestructuras y la Directiva 2011/76/UE, del Parlamento Europeo y del Consejo, de 27 de septiembre de 2011, que la modifica, admiten la posibilidad de establecer peajes a los vehículos pesados de transporte de mercancías asociados a los costes de la infraestructura y/o a los costes externos. También introducen cambios en el ámbito de aplicación y en los criterios para el cálculo de dichos peajes, incluidos aquéllos correspondientes a autopistas de peaje en régimen de concesión. A nivel interno, existe un cambio evidente en la norma derogada - Ley 25/1988, de 29 de julio, de Carreteras, en el artículo 16.1- donde el establecimiento del peaje es una excepción y en la actual - Ley 37/2015, de 29 de septiembre, de Carreteras, en su artículo 22.2- donde es una opción en igualdad de condiciones.

(29) Estamos frente al denominado "peaje sombra.» El concesionario no cobra un peaje a los usuarios, para los que el uso de la infraestructura es gratuito. La remuneración es satisfecha por la propia Administración en base al nivel de utilización de la infraestructura y de otros factores relacionados con la calidad del servicio. También cabe un sistema de remuneración mixto o "peaje blando", en el que existe un pago por los usuarios que no cubre la totalidad del importe para la financiación de la obra, y un "peaje sombra" de la Administración por el resto del coste. Véase a RODRíGUEZ MÁRQUEZ. J. "Los sistemas de colaboración público-privada para la provisión de bienes y servicios públicos. Su incidencia en el sistema de ingresos públicos", en Revista española de control externo, n. ${ }^{\circ}$ 28, 2008, págs. 111-140; VASSALLO MAGRO. J. M. y PÉREZ DE VILLAR CRUZ. P. «Diez años de peaje sombra en España", en Revista de Obras Públicas, n. ${ }^{\circ}$ 3.506, año 157, 2010. 
Para calificar la construcción y explotación de un túnel de contrato de concesión de obra pública, además de la propia construcción de la infraestructura del túnel, resulta esencial para el concepto que sea susceptible de explotación por el concesionario. (30)ARIÑO ORTIZ (31) entiende que la construcción de la obra es un mero presupuesto o soporte de lo que, en realidad, es el objeto del contrato: su explotación con apertura al público.

La obra ha de ser susceptible de explotación económica porque tiene por objeto proveer a la colectividad de un determinado servicio de interés general: en este caso, el tránsito y transporte de personas y mercancías con incidencia marcadamente económica, posibilitando con ello el crecimiento y el desarrollo económico de la zona donde se ubica la infraestructura y del conjunto en general.

El derecho de explotación del túnel permite una retribución al concesionario, que podrá adoptar modalidades distintas, entre las que destaca la posibilidad de cobrar al usuario por la utilización de la obra (peaje), sin que ello pueda determinar una exclusión de la responsabilidad de la explotación o riesgo operacional, para el concesionario(32).

\subsection{TÚNEL DE PEAJE}

Construida la infraestructura del túnel y abierto al público, los usuarios pueden utilizarla gratuitamente o mediante un peaje como contraprestación por su uso.

La naturaleza jurídica del peaje es la de ser una tarifa, un precio privado. El Tribunal Supremo, en sentencia de 20 de mayo de 2013 (RJ 2013\4685), concluye que la naturaleza jurídica del peaje es la de una "contraprestación de derecho privado" abonada como precio a una entidad privada en medio de una relación jurídica de índole contractual. La competencia administrativa para su fijación corresponde al ejercicio de la potestad tarifaria, que opera en el contexto de una relación económica de

(30) Concepción presente en la Ley $9 / 2017$, de 8 de noviembre, de Contratos del Sector público al señalar, como objeto de la concesión de obras, la realización de ciertas prestaciones por el concesionario con contraprestación a favor de aquél, consistente o bien únicamente en el derecho a explotar la obra o bien en dicho derecho acompañado del de percibir un precio (artículos 13 y 14). La explotación de la obra conlleva la transferencia al concesionario de un riesgo operacional, comprensivo del riesgo de demanda o el de suministro o ambos, debiendo conocer y asumir el concesionario que, durante la vida de la concesión, estará expuesto a las incertidumbres ordinarias del mercado (artículo 14. 4).

(31) Op. cit., pág. 17.

(32) Esta compartición de riesgos no excluye el riesgo operacional si la Administración, con ello, no elimina el riesgo inherente a la explotación. 
carácter sinalagmático y su percepción responde a un régimen de derecho privado, que disciplina las relaciones entre la sociedad explotadora y el usuario y no a uno de derecho público como es el que disciplina los créditos de la Hacienda pública con los ciudadanos contribuyentes, lo que excluye su consideración de prestación patrimonial de carácter público del artículo 31. 3 de la Constitución.

El peaje es un elemento destacado en la relación contractual en la medida que se integra en el derecho del concesionario a la explotación -objeto de la concesión - y que trata de garantizar su equilibrio económico financiero. TORNOS MAS (33) reconoce en el peaje un «claro matiz contractual" pues, aun siendo fijado unilateralmente por la Administración titular del servicio, su cuantía se vincula al objeto del servicio y puede verse afectado en su determinación por la ruptura del equilibrio financiero del contrato.

El peaje por el uso de la infraestructura, aun cuando cumpla una función principal de mecanismo financiero, debe evolucionar en su concepción hasta alcanzar la significación de precio por un servicio diferencial(34). Por ello, además de servir al cometido principal de financiar la construcción y de mantener la infraestructura, debe valer para gestionar la demanda de tráfico eficientemente, reinvertir en seguridad, servir factor de integración territorial y social, potenciar la apertura de mercados y el fomento del turismo y asumir ciertos compromisos medioambientales.

La imposición del peaje por el uso de la infraestructura presupone la existencia de una vía alternativa, de manera que haya otra forma de paso que permita llegar al mismo destino, aun cuando esta última implique un tráfico más complicado: más tiempo, más congestión y menos seguridad. De no existir la alternativa, la imposición de un peaje podría verse como una limitación discriminatoria al libre tránsito de algún sector de la población, lo que podría corregirse con el reconocimiento de ciertos estímulos, como bonificaciones, a favor de los usuarios más afectados por su imposición.

\section{Antecedentes}

En fecha de 19 de septiembre de 1986, la empresa Viales y Estacionamientos, S.A., (VYESA) presentó ante la Consellería de Obras Públicas y

(33) "Potestad tarifaria y política de precios», en Revista de Administración Pública n. ${ }^{\circ}$ 135, 1994, pág. 80.

(34) ROBUSTÉ ANTÓN. F., «El peaje en autopistas como precio por un servicio y como garante de sostenibilidad", en Revista de Obras Públicas n. ${ }^{\circ}$. extra 3425, 2002, págs. 127-139 (ejemplar sobre El nuevo sistema concesional. Consideraciones sobre el proyecto de ley reguladora del contrato de concesión de obras públicas). 
de Ordenación del Territorio un escrito en el que exponía el problema de la Carretera C-711 - entre los puntos kilométricos 17 al 28 - en su paso de la Sierra de Alfabia, proponiendo la construcción de un túnel y llegando a la conclusión de la conveniencia de instrumentarlo a través de un contrato de obra pública en régimen de concesión de peaje. A esta propuesta, se unirían otras posteriormente.

El día 6 de abril de 1988 (BOCAIB de 14 abril de 1988), el Pleno del Parlamento Balear aprobó y otorgó su conformidad a una serie de Resoluciones relativas al Anteproyecto del túnel de Sóller.

En fecha 6 de julio de 1988 (BOCAIB de 21 de julio de 1988), el Gobierno Balear convocó el concurso para la adjudicación de la «concesión para la construcción, conservación y explotación, como carretera de peaje, de la variante de la C-711 con túnel que cruce la sierra de Alfabia».

Por Decreto 86/1988 de 18 de noviembre (BOCAIB de 22 de diciembre), la concesión se adjudicó a la oferta encabezada por D. Antonio Cuart Ripoll a lo que le siguió la constitución de la sociedad adjudicataria «Compañía Concesionaria delTúnel de Sóller». El plan de ejecución de las obras pasaba por las fases siguientes: presentación del Proyecto (4 meses), inicio de las obras (6 meses), terminación de las obras (24 meses), apertura al tráfico (26 meses), todos ellos computados a partir de su entrada en vigor que fue el día 23 de diciembre de 1988. Las obras ni cumplieron las previsiones temporales señaladas ni estuvieron terminadas en el plazo previsto sino seis años después, inaugurándolas el 19 de febrero de 1997 (35).

El 20 de agosto de 1997, la empresa concesionaria del túnel de Sóller presentó reclamación ante la Administración Balear solicitando el restablecimiento del equilibrio económico de la concesión por el retraso sufrido en la conclusión de las obras con el correlativo acortamiento del periodo concesional inicialmente previsto y por el incremento de los costes derivados de circunstancias imputables a la Administración.

Ante el silencio desestimatorio de la Administración Balear, la concesionaria interpuso recurso contencioso-administrativo resuelto por el Tribunal Superior de Justicia de las Islas Baleares, en sentencia de 12 de marzo de 2004 (1277/2004). El fallo favorable a la concesionaria disponía que la Administración demandada debía abonarle: a) la cantidad de

\footnotetext{
(35) Las causas: la mala planificación extensiva al estado del terreno, con derrumbe de rocas a 500 metros de la boca norte del túnel en 1990 supuso una de las primeras pausas en el proyecto, el inadecuado diseño de los accesos incluidos en el anteproyecto con modificación y ampliación con realización de obras complementarias (diversas canalizaciones para el "aprovechamiento de Aguas de Sa Costera y Torrente Mayor de Sóller» y de las Compañías Gesa y Telefónica) y los sobrecostes añadidos por las sucesivas revisiones de precios respecto a lo pactado con la empresa contratista, provocaron quiebra de la concesionaria con un nuevo parón en las obras hasta que Fomento de Construcciones y Contratas (FCC) acabó haciéndose con la concesión, reanudándose las obras a finales de 1994.
} 
2.941.457,55 euros (489.417.356 ptas.), IVA excluido, con el interés legal del mismo, incrementado en 1,5 puntos, a partir de los seis meses siguientes a la recepción; b) los gastos financieros intercalarios producidos por el retraso - en diez meses - en la puesta en servicio del túnel, y en la cuantía que se determine en ejecución de sentencia; c) el lucro cesante derivado de la pérdida de explotación por plazo de diez meses, que igualmente se determinará en ejecución de sentencia, sin hacer expresa declaración en cuanto a costas procesales.

Por Auto aclaratorio de 19 de abril de 2004(Auto $n .^{\circ}$ 1908/98) y, en relación a los puntos b) y c) del tercer pronunciamiento de la sentencia $212 / 2004$, se dispuso que el resarcimiento a la concesionaria podría articularse "a elección de la Administración, por medio de subvención, revisión de tarifas, prórroga de la concesión o por medio de todas o parte de estas medidas".

Como consecuencia de ambas decisiones judiciales $-y$ en ejecución de los fallos emitidos - la concesión sufrió dos modificaciones: Con la primera -26 de julio de 2004- el Pleno del Consejo de Mallorca acordó modificar determinados términos de la concesión administrativa con la aprobación de un convenio de colaboración para las instalaciones de control del Túnel de Sóller, firmado el día 28 de septiembre de 2004 entre el Consejo Insular de Mallorca y la Concesionaria, donde se indica que el Plan económico-financiero presentado por la Compañía concesionaria del Túnel de Sóller constituye la base económico-financiera y que, en adelante, regirá la concesión. Con la segunda -10 de septiembre de 2007el Pleno del Consell de Mallorca acordó modificar la duración de la concesión administrativa hasta el día 30 de junio de 2022; aprobar un nuevo Plan económico-financiero - presentado por la concesionaria el 24 de enero de 2007- que, una vez firmado por las partes, pasaba a regir el contrato de concesión; y mantener la vigencia del convenio de 28 de septiembre 2004 excepto en el Plan económico-financiero, sustituido por el aprobado el 24 de enero de 2007.

El 2 de agosto de 2017, el Pleno del Consell Insular de Mallorca ratifico y aprobó el acuerdo de rescate de 6 de marzo de 2017 que fue notificado a la concesionaria el 15 de marzo de 2017 para que presentara alegaciones, lo que hizo en el mes de abril. En ellas, la concesionaria se opone al rescate en sí y a la cuantificación indemnizatoria calculada para resarcirle.

\section{Pronunciamientos emitidos}

La complejidad de la decisión de rescatar la concesión de obra pública del túnel de peaje de Sóller queda de manifiesto por la variedad y el alcance de los pronunciamientos emitidos. 


\subsection{LA APROBACIÓN DE LA PROPUESTA DE RESCATE}

El 6 de marzo de 2017, en sesión extraordinaria, el Pleno del Consell de Mallorca aprobó iniciar el procedimiento para rescatar la concesión del túnel de Sóller. La especifica razón de interés general alegada era garantizar la igualdad de trato para todos los usuarios del túnel, dado que el Consell de Mallorca construye y mantiene todas las infraestructuras de la red de carreteras de la Isla de Mallorca con dinero público. Esta propuesta se hacía eco de una anterior petición del Ayuntamiento de Sóller que, en septiembre de 2015, instaba al Gobierno Balear y al Consell de Mallorca a acordar y proceder al rescate de la concesión del túnel de Sóller, alegando que ésta constituye una desventaja en materia de comunicaciones y transportes, una penalización inaceptable y un sobrecoste inasumible para los ciudadanos y para todas las personas que se relacionan con el Valle de Sóller; reivindicación compartida por los Gobiernos locales de otros municipios como Fornalutx, Bunyola y Escorça, también afectados por el túnel.

\subsection{El Dictamen del Consejo Consultivo de las Islas Baleares}

El dictamen preceptivo, de conformidad con lo dispuesto en la normativa general en materia de Contratos del Sector público (36) y en la especifica de este Alto organismo (Ley 5/2010, de 16 de junio, reguladora del Consejo Consultivo de las Islas Baleares, en su artículo 18.12.c)), constituye una garantía de regularidad del procedimiento, cuya omisión podría acarrear la invalidez de la decisión de rescate. La solicitud de este dictamen, a petición del Presidente del Consejo Insular de Mallorca, tuvo lugar el 22 de mayo de 2017. El Consejo Consultivo de las Islas Baleares dictaminó favorablemente la decisión de rescatar el túnel de Sóller el 2 de julio de 2017 (37). El sentido favorable del dictamen quedaba condicionado a que la Administración Balear atendiera a una serie de observaciones relativas al montante indemnizatorio del rescate donde, pese a mostrar una posición próxima a la cuantía indemnizatoria propuesta, aconsejaba sopesar la repercusión de los impuestos del IBI y del IVA en la partida relativa a "otros daños y perjuicios».

(36) Artículos 211 del RD legislativo 3/2011, de 14 de noviembre, 109.1 del Real Decreto 1098/2001, de 12 de octubre y 114 del Real decreto legislativo 781/1986, de 18 de abril en materia de régimen local.

(37) Dictamen 91/2017. 


\subsection{LA RESOLUCIÓN SOBRE EL RESCATE}

La resolución de rescate de 2 de agosto de 2017 se separa de las observaciones realizadas por el Consejo Consultivo, al no tener carácter vinculante, y confirma la anterior propuesta de rescate en los términos siguientes: desestima las alegaciones de la Compañía Concesionaria del Túnel de Sóller, ratifica los motivos del interés público que motivaron el inicio del expediente del rescate, fija la indemnización del concesionario en la cantidad de 17.404.179,18 $€$ y autoriza un gasto por ese importe que se financiará con cargo a una serie de partidas presupuestarias que delimita expresamente.

\subsection{El Auto del Juzgado Contencioso-Administrativo de suspensión del RESCATE}

Por Auto n. ${ }^{\circ}$ 167/2017, de 25 de agosto de 2017, el Juzgado Contencioso-Administrativo $n .{ }^{\circ} 3$ de las Islas Baleares acordó la suspensión cautelar del acuerdo de rescate de 6 de marzo de 2017 (38). Con el reconocimiento de esta medida cautelar confirma la cautelarísima, concedida por Auto de 17 de agosto de 2017, suspendiendo la ejecutividad del rescate por la «perentoriedad individualizada que supondría, de tener eficacia el acto el 1 de septiembre, la extinción de la persona jurídica solicitante, así como la obligación de abono de elevadas cantidades que vencen anticipadamente, no pudiendo acudirse a otro instituto que permita proteger, siquiera temporalmente, tales intereses». El Auto dispone mantener la suspensión hasta la sentencia firme que ponga fin al proceso, sin perjuicio de modificación o revocación de cambiar las circunstancias presentes, y condena en costas a la Administración demandada. Esta decisión fue recurrida por el Consejo Insular de Mallorca

\subsection{El Auto del Tribunal Superior de Justicia de las Islas Baleares oue deja SIN EFECTO LA MEDIDA CAUTELAR DE SUSPENSIÓN DEL RESCATE}

El Auto n. ${ }^{\circ}$ 185/2017, de 13 de diciembre de 2017 (n. ${ }^{\circ}$ 00185/2017) del Tribunal Superior de Justicia de las Islas Baleares, al estimar el recurso interpuesto, revoca el auto apelado y deniega la medida cautelar de suspensión anteriormente concedida.

(38) Alejandro González Mariscal de Gante, Magistrado-juez del Juzgado. Contencioso/Administrativo. n. ${ }^{\circ} 3$ de Palma de Mallorca. 
El Tribunal justifica la denegación de la medida cautelar en que no se cumplen los requisitos del artículo 130 de la Ley de la Jurisdicción Contencioso-Administrativa (39) y en el carácter exclusivamente económico de los perjuicios irrogados al concesionario con el rescate. Esta última consideración permite denegar la medida cautelar en aplicación de la doctrina delTribunal Supremo por la que "la ejecución de actos administrativos de tal naturaleza, salvo excepciones específicas y acreditadas por las especiales circunstancias que lo rodean puedan hacer procedente la suspensión de su ejecutividad, no genera perjuicios de imposible o difícil reparación, toda vez que la Administración es por su propia naturaleza, organización y funcionamiento, una entidad pública responsable y solvente en grado máximo, por lo que la posible existencia de esos perjuicios económicos derivados de la ejecución del acto administrativo que posteriormente fuese anulado en vía jurisdiccional, no puede ofrecer ni ofrece dificultades en cuanto a la adecuada reparación de los perjuicios y daños causados fácilmente conseguible dada la solvencia de la Administración» (40).

\title{
4. Problemas jurídicos que suscita
}

Decisivo para la correcta solución de los interrogantes planteados por el rescate de la concesión del túnel de peaje de Sóller es determinar la

\begin{abstract}
(39) A nuestro juicio el Tribunal realiza una incorrecta valoración de los requisitos del art.130 de la LJCA y acepta por válida una afirmación del Consejo insular que no es exacta ya que la Administración Insular señala que la concesión «se encuentra en una fase de prórroga y no en el período concesional inicial" lo que es una verdad a medias, sin reparar que la "prorroga" lo es en ejecución de un fallo judicial que, en su día, reconoció el derecho al concesionario a alargar el plazo de la concesión no como un plus añadido a la duración inicial de la concesión sino para compensarle por los años de retraso en la apertura y explotación. Existe una decisión judicial que ampara al concesionario a mantenerse en la concesión hasta 2022 que podría interpretarse como un fumus boni iuris que refuerza su posición al solicitar la cautelar de suspensión que no ha sido valorado. Por otro lado, el Tribunal no sopesa todos los intereses implicados centrándose en los del concesionario, que califica de económicos, sin valorar otros perjuicios como él que para la ciudadanía supondrá asumir el coste del rescate, y la pérdida de puestos de trabajo del personal de la concesionaria. Tampoco justifica qué perjuicio supone para la Administración Insular no rescatar anticipadamente y tener que esperar al vencimiento natural de la concesión. Esta inadecuada ponderación de todos los intereses implicados no permite sopesar cuál es el interés prevalente.
\end{abstract}

(40) Esta doctrina se asienta sobre la creencia de que la Administración Publica siempre es solvente y proviene de la Sala Tercera de Tribunal Supremo tal y como viene referenciado en sentencia n. ${ }^{\circ}$ 215/2017 del Tribunal Superior de Justicia de Comunidad Valenciana, Sección 1, n. ${ }^{\circ}$ rec. 344/2016 de 30 de Marzo de 2017, concretamente los Autos de 3 de junio de 1992, 14 de enero de 1992, 28 de septiembre de 1994, 19 de marzo de 1997, entre otros). Existen sentencias que, en atención al supuesto concreto enjuiciado, no aplican este criterio por entender que se parte de un presupuesto irreal. Entre otras, la sentencia delTSJ de Murcia de 27 de mayo de 2011 (n. ${ }^{\circ}$ rec. 396/2010), considera: «Tampoco es un argumento de peso afirmar que la solvencia de la Administración local se presume para el caso de que tenga que devolver las indemnizaciones pagadas por la concesionaria, ya que son conocidas, en la actual época de crisis las dificultades que incluso la Administración puede tener para hacer frente a sus obligaciones diarias». 
normativa aplicable al encontrarnos ante una relación de larga duración - años 1988 a 2022-donde incide, no sólo el transcurso del tiempo con los posibles cambios legislativos acaecidos en ese periodo temporal sino también una sucesión de acontecimientos a valorar para poder alcanzar la solución más acorde a Derecho.

\subsection{LA NORMATIVA APLICABLE}

Durante la vigencia de la concesión del túnel de Sóller, la normativa ha ido modificándose al ritmo de los cambios legislativos que se han ido sucediendo en el tiempo y que han incidido en distintas fases de la misma acompasando su evolución, como exponemos a continuación.

-En fase de adjudicación de la concesión. Cuando la concesión se adjudicó en 1988(41), la normativa aplicable la constituía el propio contrato y la legislación vigente en la materia en ese momento a la que éste remitía (42).

-En fase de novación de la concesión en 2004 y 2007. Las sentencias del Tribunal Superior de Justicia de las Islas Baleares de 12 de marzo de 2004 y de 19 de abril de 2004 posibilitaron la modificación del plazo de la concesión y de su Plan económico-financiero, como mecanismo del cumplimiento del fallo emitido. Este hecho obliga a plantearse si, a partir de las modificaciones introducidas en estos años, resulta aplicable la legislación originaria o la dictada con posterioridad porque desde la adjudicación de la concesión en 1988 hasta las sucesivas modificaciones en 2004 y 2007 aparecen regulaciones nuevas con repercusión en la materia, como sucede con la Ley 13/1995, de 18 de mayo, de Contratos de las Administraciones públicas que derogó las leyes anteriores sobre Contratos del Estado; el Real Decreto legislativo 2/2000, de 16 de junio, que aprueba el Texto refun-

(41) La adjudicación se formalizó el día 23 de febrero de 1989.

(42) Por entonces estaban vigentes normas específicas (Ley sobre construcción, conservación, explotación de Autopistas en régimen de concesión de 10 de mayo de 1972, Pliego de Cláusulas Generales para la construcción, conservación y explotación de Autopistas en régimen de concesión, aprobado por Decreto 215/1973, de 25 de enero, Pliego de Bases del Concurso y de Clausulas Particulares aprobados por el Consejo de Gobierno de la Comunidad Autónoma de las Islas Baleares, de 9 de junio de 1988, Ley de Carreteras de 29 de julio de 1988) y normas generales, como la legislación de Contratos (Ley de Bases de Contratación del Estado de 28 de diciembre de 1963, su Texto articulado de 8 de abril de 1965, el Reglamento de Contratación del Estado de 28 de diciembre 1967, parcialmente modificados por Ley 5/1973, de 17 marzo y Decreto 3410/1975, de 25 de noviembre. Normas estas que, como consecuencia de la incorporación de España a la Unión Europea en 1986, serían modificadas por el Real Decreto Legislativo 931/1986, de 2 de mayo y por el Real Decreto 2528/1986, de 28 de noviembre). 
dido de la Ley de Contratos de las Administraciones Públicas; el Real decreto 1098/2001, de 12 de octubre que aprueba el Reglamento General de la Ley de Contratos de las Administraciones Públicas; la Ley 13/2003, de 23 de mayo, reguladora del Contrato de concesión de obras públicas y la Ley 30/2007, de 30 de octubre, de Contratos del Sector Público.

-En fase de resolución del rescate. Desde 2007 -última novación- a la actualidad se han dictado el Decreto Legislativo 3/2011, de 14 noviembre, que aprueba el Texto refundido de la Ley de Contratos del Sector Público, posteriormente modificado y completado por numerosas normativas sectoriales y la reciente Ley 9/2017, de 8 de noviembre, de Contratos del Sector Público que deroga la anterior e introduce cambios en la regulación del rescate que, dependiendo de la interpretación que demos a la cláusula de transitoriedad, podría afectar o no a la resolución de rescate relativa al túnel de Sóller.

A su vez, para poder decidir la normativa aplicable resulta relevante tener presente tres cuestiones: Primera, la naturaleza contractual de la concesión y la necesidad de estar al principio de pacta sunt servanda. Segunda, la previsión de un régimen de transitoriedad y la delimitación de su alcance. Por último, el carácter novatorio, extintivo o no, de las modificaciones operadas en la concesión.

- La naturaleza contractual de la concesión y la necesidad de estar al principio de pacta sunt servanda. Atendiendo a la naturaleza contractual de la concesión de obra pública y de acuerdo con los más elementales principios jurídicos en contratación privada y pública, los pactos están para cumplirse pues el contrato obliga a los contratantes y debe ser puntualmente cumplido respetando los términos del mismo, teniendo prioridad lo dispuesto en él, siempre y cuando sus estipulaciones no contradigan el interés público, el Ordenamiento jurídico y los principios de buena administración.

Que los contratos son obligatorios y que las obligaciones nacidas de los mismos tienen fuerza de ley entre las partes contratantes deriva de la propia Norma (artículos 1091 y 1278 del Código Civil) que otorga esa vinculación a la común voluntad de las partes, hasta el punto de no poder dejarse su validez y cumplimiento al arbitrio de uno de los contratantes (artículo 1256 Código Civil).

Todos los instrumentos normativos que regulan la concesión delTúnel de Sóller respetan estas prescripciones. Los Pliegos (43) indican que sus

(43) El Pliego de Bases para el concurso de construcción, conservación y explotación, del túnel de Sóller (Base $10 .^{\text {a) }}$ y el Pliego de Cláusulas Particulares que rige la concesión del túnel de Sóller (Título Primero) así lo recogen. 
cláusulas rigen la vida de la concesión y, en su defecto, lo hará la normativa vigente aplicable en la materia. El Decreto de adjudicación de la concesión remite al contrato como normativa reguladora $y$, en su defecto, a la normativa vigente aplicable. El propio documento de formalización del contrato dispone la prioridad de lo estipulado en él y señala, en su cláusula undécima como la sociedad concesionaria queda vinculada frente a la Comunidad Autónoma en los términos contenidos en su proposición, con las modificaciones introducidas y aceptadas por el licitador/adjudicatario y en lo no regulado por el contrato por "las normas contenidas en el Decreto 86/88, de 18 de noviembre, en la Ley 8/1.972, de 10 de mayo, en el Pliego de Cláusulas Generales, aprobado par Decreto 215/1.973, de 25 de enero, en el Pliego de Bases del Concurso y de Clausulas Particulares, aprobados por el Consejo de Gobierno de la Comunidad Autónoma de las Islas Baleares el 9 de junio de 1.988, y con carácter general, por las preceptos contenidos en la vigente legislación de contratos».

-El régimen de la transitoriedad y su alcance. En términos generales, el problema de la transitoriedad de las normas debe resolverse a través de lo que disponga la última normativa dictada si, en ella, se ha previsto el Derecho aplicable a las relaciones constituidas bajo la normativa anterior que siguen vigentes en el momento de su entrada en vigor. Sólo en caso de no existir una norma que regule expresamente esta cuestión se estará, supletoriamente, a lo dispuesto en el Código civil (44).

La legislación vigente en las distintas etapas de la concesión del túnel de Sóller sí contiene una norma transitoria que ha ido evolucionando $y$ adquiriendo, con el tiempo, un mayor grado de precisión (45).

(44) El Consejo de Estado, en dictamen $n .^{\circ} 3.678 / 1997$, se muestra favorable a aplicar las disposiciones transitorias del Código Civil (erigidas en «derecho intertemporal común») que prevén que, a falta de norma específica, "los actos y contratos celebrados bajo el régimen de la legislación anterior, y que sean válidos con arreglo a ella, surtirán todos sus efectos según la misma.»

(45) La evolución es la siguiente: La Ley 5/1973, de 17 de marzo, de Contratos del Estado establecía que dicha regulación solo se aplicará a los pliegos de cláusulas administrativas particulares, de explotación o de bases aprobados con posterioridad a dicha fecha y su Reglamento, de 25 de noviembre de 1975, matizaba que la normativa contenida en él únicamente afecta a las actuaciones que se realicen con posterioridad a su entrada en vigor; La Ley 13/1995, de 18 de mayo, de Contratos de las Administraciones Públicas determinaba que su regulación se extendía a los expedientes de contratación en curso ya adjudicados y el Decreto Legislativo $2 / 2000$, de 16 de junio, y la Ley de 23 de mayo de 2003, reguladora del Contrato de concesión de obras públicas refiere la adjudicación al momento de la publicación de la convocatoria; La Ley 30/2007, de 30 de octubre de 2007, de Contratos del Sector Público introduce diferencias, en el alcance de la transitoriedad, por primera vez, y puntualiza que los contratos administrativos adjudicados con anterioridad a la entrada en vigor de la presente Ley se regirán por la normativa anterior sólo "en cuanto a sus efectos, cumplimiento y extinción, incluida su duración y régimen de prórrogas"; criterio reproducido en el Decreto Legislativo 3/2011, de 14 de noviembre, que aprueba el Texto refundido de la Ley de Contratos del Sector Público; Finalmente, la Ley 9/2017, de 8 de noviembre, de Contratos del Sector Público modifica parcialmente el alcance de la transitoriedad al hacerlo extensivo también a la «modificación del contra- 
También, en relación con el alcance de la transitoriedad, surge la cuestión relativa a la disparidad existente entre lo que, literalmente, dispone la legislación respecto a la aplicación de la normativa anterior "a efectos de cumplimiento, modificación y extinción, incluida su duración y régimen de prórrogas, de los contratos ya adjudicados" y el criterio del Consejo de Estado y homónimos autonómicos, con reflejo en alguna jurisprudencia, favorable a separar de aquellos los aspectos relativos a la competencia y al procedimiento del rescate que se regirán por la normativa vigente en el momento de proceder al rescate; quizás el futuro Reglamento de desarrollo debería aportar luz y consenso sobre estas discrepancias manifiestas en la legislación y en la práctica.

Ante este abanico de posibilidades, nos posicionamos a favor de entender aplicable la normativa vigente y coetánea al momento del nacimiento de la concesión cuando este criterio se recoja en su clausulado. Ello no está reñido con que dicha normativa sea interpretada en coherencia con la dictada posteriormente, cuando no resulte radicalmente incompatible con el contenido básico de la que constituye la regulación preferente, muy especialmente si la legislación última es fruto de la adaptación de la normativa interna a la legislación Europea o a dictados constitucionales (46).

-El carácter novatorio, extintivo o no, de las modificaciones operadas en la concesión. Resulta relevante determinar si las modificaciones, experimentadas por la concesión que la novan indudablemente, tienen carácter extintivo o modificativo. $Y$ es relevante porque si la novación opera con efecto extintivo, tendríamos que concluir que la normativa aplicable a la concesión es la vigente a partir de la fecha de su novación.

Aunque cualquier modificación de los elementos de un contrato determina su novación, ésta podrá ser extintiva o modificativa en atención a su mayor o menor alcance. En la novación extintiva o propia, las obligaciones existentes con anterioridad se extinguen y quedan sustituidas por las nuevas. El artículo 1204 del Código Civil dispone que «para que una obligación quede extinguida por otra que la sustituya, es preciso que así se declare terminantemente, o que la antigua y la nueva sean de todo punto incompatibles" de lo que se extrae que el efecto extintivo no cabe inferirse de meras deducciones sino que ha de constar de forma inequívoca.

to" y resalta que la nueva normativa será de aplicación al rescate cuando éste se efectué con posterioridad a su entrada en vigor, sin concretar si la nueva regulación incide en cualquier momento o fase de la concesión o sólo a partir del pronunciamiento del rescate.

(46) Un ejemplo lo encontramos en el art. 135 de la CE y la Ley Orgánica 2/2012, de 27 de abril, de Estabilidad Presupuestaria y Sostenibilidad Financiera así como la Ley 27/2013, de 27 de diciembre, de Racionalización y sostenibilidad de la Administración Local que sí resultan aplicables a todas las concesiones vigentes en las exigencias de sostenibilidad y eficiencia. 
La novación modificativa o impropia excluye la voluntad de extinguir la obligación anterior resultando relevante, atender a la voluntad de las partes y a la significación económica de la modificación introducida, para llegar a esta conclusión. Si la obligación subsiste, pese a variar alguna de sus condiciones principales, y permanece el vínculo aunque modificado, estamos ante una novación meramente modificativa. A tenor de la jurisprudencia(47) «no cabe apreciar ningún impedimento jurídico para que las partes que han dispuesto la autorregulación de sus respectivos intereses mediante el otorgamiento del oportuno contrato puedan, en aplicación del principio general de autonomía de la voluntad que sanciona el artículo 1.255 del CC, introducir en dicho contrato, subsistiendo el mismo vínculo contractual, las modificaciones que tengan por conveniente novando impropiamente de esta forma aquél», constituyendo la novación modificativa la regla general, en caso de duda.

Coherentes con estas afirmaciones, entendemos que las sucesivas modificaciones de la concesión del túnel de peaje de Sóller en los años 2004 y 2007 tienen alcance modificatorio, dados los propios términos de las estipulaciones contenidas en contrato de novación de la concesión firmado el 24 de octubre de 2007, en cuyas clausulas se estableció: prorrogar la concesión en cinco años y seis meses, elaborar un nuevo Plan económico-financiero ajustado a ese nuevo período, mantener los términos del convenio de 28 de septiembre de 2004 y, en particular, considerar ley del contrato lo estipulado en concesión de 23 de febrero de 1989 salvo en lo relativo al Plan económico-financiero que regirá lo estipulado en 2007.

De entre los elementos novados, la prórroga del término inicial merece un comentario destacado para determinar si afecta a un elemento sustancial o no de la concesión y para concluir, sin sombra de dudas, sobre el alcance modificatorio o extintivo de la misma; hay que recordar que éste es una condición de la licitación importantísima (48) con una clara vertiente económica y que la prórroga no siempre tiene por qué obedecer a idénticos supuestos ni ser valorada de igual manera (49).

(47) Sentencia delTribunal Supremo de 29 de enero de 1982, RJ 19821335.

(48) La prórroga o ampliación del plazo de concesiones es una cuestión extremadamente delicada por afectar al principio de libre concurrencia. El artículo 157 de la Ley 13/1996, de 30 de diciembre, de Medidas Fiscales, Administrativas y del Orden Social, añadió un artículo 25 bis a la Ley 8/1972, de 10 de mayo, sobre Construcción, conservación y explotación de Autopistas en régimen de concesión donde introduce la posibilidad de que la compensación al concesionario pueda consistir, total o parcialmente, en la ampliación del plazo vigente de la concesión, con el propósito de mantener el equilibrio económico-financiero de la concesión, en los supuestos de modificación.

(49) Esta problemática es estudiada por GALLEGO CÓRCOLES. I., "La modificación de los contratos en la cuarta generación de directivas sobre contratación pública» en Las nuevas Directivas de Contratación Pública, (Ponencias sectoriales X Congreso Asociación Española Profesores de Derecho Administrativo) en Contratos Públicos, Número monográfico Especial (2015) págs. 120 y 121. 
Existe un debate inacabado(50) sobre si alterar la duración inicial de una concesión constituye o no una modificación sustancial de la misma y sobre si el contrato prorrogado es el mismo contrato renovado o un nuevo contrato. Mayoritariamente, se admite que la prorroga no constituye una modificación sustantiva cuando viene autorizada legalmente o está prevista en los Pliegos de la concesión. Al margen de estas previsiones, la prórroga es contraria a Derecho con la salvedad de que su incorporación obedezca a la concurrencia de circunstancias excepcionales (51).

En el caso analizado de la concesión del túnel de Sóller, la prórroga se convierte en una fórmula de reequilibrio económico-financiero, consecuencia de las situaciones adversas por las que paso la concesionaria con el propósito de materializar y dar cumplimiento a la indemnización que el Tribunal Superior de Justicia de Baleares reconoció a favor de la concesionaria. La concesión de la prórroga determinó una alteración de las condiciones económicas iniciales, reformulándose el modelo económico-financiero de la concesión, sin producirse la extinción del contrato inicial con sustitución de otro nuevo sino una mera modificación parcial del anterior. El propio contrato, modificado en 2007, lo reconoce cuando admite regularse por la normativa vigente en el momento de su adjudicación, lo que corrobora que nos encontramos ante una modificación del contrato inicial.

\subsection{EN ESPECIAL}

Tras estas conclusiones generales sobre la normativa reguladora de la concesión, corresponde detenernos en tres cuestiones específicas en las que la correcta elección de la legislación aplicable resulta crucial para valorar la legalidad del rescate de la concesión del túnel de Sóller.

(50) AGUDO GONZÁLEZ. J., «El tiempo en las concesiones de servicio público. Continuidad en la prestación del servicio y potestas variandi versus libre concurrencia», en Revista General de Derecho Administrativo n. ${ }^{\circ}$ 26, 2011, págs. 1-45; AGUADO I CUDOLÀ. V., "Efectos de la invalidez y prórroga de los contratos públicos," Ponencia para el XII Congreso de la Asociación Española de Profesores de Derecho Administrativo, La Laguna, 3 y 4 de febrero de 2017; y GALLEGO CÓRCOLES. I (Op. cit.).

(51) AGUDO GONZÁLEZ. J. (Op. cit. págs. 22 y 23) afirma que los principios de igualdad de trato y de transparencia, con el objetivo de garantizar la libre concurrencia, se alzan como límites al principio de continuidad en lo que atañe a la prórroga o ampliación del plazo concesional, cuando esa posibilidad no haya sido expresamente prevista en los documentos que rigen la licitación, justificándola en situaciones excepcionales aun cuando ello pudiera poner de relieve una falta de previsión y diligencia administrativa. 


\subsubsection{La competencia para el rescate}

La competencia y la atribución sobre a quién corresponde rescatar fue alterada a lo largo de la vida de la concesión, con la secuencia siguiente. En 1988, la Comunidad Autónoma Balear, a través de su Consejo de Gobierno, adjudicó, por medio del Decreto 86/1.988, de 18 de noviembre, la concesión administrativa para la construcción, conservación y explotación de la variante de la Carretera C-711, de Palma a Sóller, con Túnel que cruza la Sierra de Alfabia. En 2001, la Ley 16/2001, de 14 de desembre, sobre atribución de competencias en materia de carreteras y caminos alteró lo que, inicialmente, era una competencia autonómica para transferirla al Consejo Insular de Mallorca. La Ley reconocía a los Consejos Insulares la titularidad de ciertas carreteras que, hasta ese momento, correspondían a la Administración Autónoma de las Islas Baleares y, con ello, las funciones ejecutivas y de gestión respecto a las mismas. En el artículo $9 .^{\circ}$ y las Disposiciones Adicionales Segunda y Quinta de la referida norma se dispuso el traspaso de los contratos en ejecución a los Consejos Insulares de Mallorca, Menorca, Ibiza y Formentera, subrogándose en los derechos y en las obligaciones relativos a los expedientes de contratación de las obras iniciadas y de los bienes citados en el anexo II de la Ley, donde se mencionaba, expresamente, a la carretera 711 con túnel de Palma a SóIler. Una vez la competencia en el Consejo Insular de Mallorca, su Pleno - por Resolución del día 17 de julio de 2015 (BOIB n. ${ }^{\circ} 111$, de 23 de julio de 2015) - acordó la delegación de la atribución en la Presidencia del Consejo Insular de Mallorca. Posteriormente, el día 6 de marzo de 2017, el Pleno del Consejo Insular de Mallorca, en sesión extraordinaria, decidió avocar la atribución delegada de manera puntual, "única y exclusivamente" para la resolución mediante rescate del contrato de construcción, conservación y explotación del túnel de Sóller, en aplicación del artículo 10.1 de la Ley 40/2015, de 1 de octubre, de Régimen Jurídico del Sector Público, justificando su decisión en la transcendencia económica y social del rescate para la Isla de Mallorca.

Las sucesivas alteraciones -intersubjetiva e interorgánica- de competencia y de atribución realizadas al amparo del Ordenamiento jurídico, permiten concluir la legalidad del rescate al corresponder legalmente la atribución para hacerlo, en el momento de adoptar la decisión, al Pleno del Consejo Insular de Mallorca.

\subsubsection{La instrucción del procedimiento}

La instrucción del procedimiento debió respetar la normativa existente en el momento de rescatar. De acuerdo con la normativa vigente, al pro- 
nunciar el rescate, los trámites exigibles eran: la audiencia y las alegaciones del concesionario - arts. 64. f) y 76 y 82 de la Ley 39/2015, de 1 de octubre-, el dictamen preceptivo del Consejo Consultivo - art. 22. $12 .^{\circ} \mathrm{de}$ la Ley Orgánica 3/1980 del Consejo de Estado, art. 211 del RD legislativo 3/2011, de 14 de noviembre de Contratos del Sector público, arts. 109.1 del Real Decreto 1098/2001, de 12 de octubre y 114 del Real Decreto legislativo 781/1986, de 18 de abril de Régimen Local y 18. 12. c) de la Ley 5/2010, de 16 de junio, reguladora del Consejo Consultivo de las Islas Baleares- y el Informe preceptivo de la Intervención General del Consejo Insular de Mallorca - art. 214. 2. a) del Real Decreto legislativo 2/2004, de 5 de marzo, que aprueba el Texto Refundido de la Ley reguladora de las Haciendas locales en relación con los arts. 177 y 180 de la misma norma y con los arts. 34 a 42 del Real Decreto 500/1990, de 20 de abril por el que se desarrolla el Capítulo primero del Título Sexto de la Ley 39/1988, de 28 de diciembre, reguladora de las Haciendas Locales, en materia de Presupuestos. La práctica de los trámites señalados corrobora la legalidad del procedimiento.

\subsubsection{La motivación de la resolución que legitima el rescate}

De acuerdo con el artículo 35 de la Ley 39/2015, de 1 de octubre, serán motivados, con sucinta referencia de hechos y fundamentos de Derecho, entre otros: a) Los actos que limiten derechos subjetivos o intereses legítimos y i) Los actos que se dicten en el ejercicio de potestades discrecionales, así como los que deban serlo en virtud de disposición legal o reglamentaria expresa, supuestos que se dan en la decisión de rescatar la concesión del túnel de Sóller porque limita, hasta el punto de suprimir, el derecho de explotación del concesionario y porque se fundamenta en una razón de interés público, cuya apreciación discrecional exige justificación.

Respecto a la razón de interés público esgrimida para rescatar, la motivación no se satisface con alegar cualquier genérico interés público sino el específico que concurra en el supuesto concreto (52). La Administración pública alega la específica razón de interés público que, a su juicio, justifica su actuación pero para que el rescate sea legal, el interés público alegado, además, debe existir y ser cierto, ser posterior, sobrevenido y pre-

(52) El Consejo de Estado, en Dictamen 50197/1987, exige un interés público debidamente acreditado, siendo "obvio que no bastaría una abstracta invocación de su concurrencia que sin mayor precisión afirmaran los órganos instructores e informantes: al contrario, esta invocación ha de quedar suficientemente justificada en términos razonables siempre que se pretenda su aplicación». 
valente al inicial (53). El interés público habrá de ser objetivo y en ningún caso producto de un cambio de circunstancias que tenga en su origen en otra decisión administrativa (factum principis), en el incumplimiento de la Administración o del concesionario o en el mero oportunismo, ideológico o de otra naturaleza.

En principio, si nadie se opone a la decisión de rescate, la razón de interés público aducida por la Administración pública será suficiente para amparar su legalidad. Sin embargo, en el caso de que el concesionario se oponga, cualquiera de las instancias, a las que corresponda valorar la legalidad del rescate, deberá examinar, en profundidad, si el interés público alegado existe y es suficiente. Precisamente - en el caso analizado - la razón de interés público esgrimida es motivo de confrontación entre la Administración Pública y el concesionario y su análisis determinante para determinar la legalidad o no del rescate. Veamos las posiciones:

-El Consejo Insular de Mallorca alega la igualdad como razón de interés público. Se trata de rescatar la concesión, eliminando el peaje, para compensar el agravio comparativo que su abono representa para los residentes de unos municipios de Mallorca respecto a otros municipios de la Isla con infraestructuras de similares características pero gratuitas. Pagar el peaje, desde esta posición, es una penalización inaceptable y su mantenimiento un sobrecosto inasumible para los ciudadanos y para todas las personas que interactúan con el Valle de Sóller.

-El concesionario niega la existencia de discriminación en el peaje. Afirma que la "concurrencia de hechos consustanciales" a la concesión no puede invocarse por la Administración como razón de interés público para ponerle fin antes del término. La elección de este medio de gestión para la construcción y explotación del túnel, a cambio de que el concesionario cobrara un peaje a los usuarios por su utilización, fue fruto de una decisión discrecional de la Administración que no puede desconocer ahora, al no haberse variado los presupuestos que propiciaron su otorgamiento pues el peaje -origen de todos los males - estuvo desde el comienzo, nadie se opuso

(53) El interés público que justifique el rescate ha de ser diferente del que, en su día, estuvo implícito en la relación que se constituyó para satisfacer, también, un concreto interés público. No debemos perder de vista que la concesión es una relación de tracto sucesivo que puede requerir variaciones durante su vigencia y donde el inicial interés público - bajo el cual se constituyó la relación- puede haberse transformado. A esta circunstancia se refiere AGUILAR VALDEZ O.R., "La extinción anticipada de concesiones en materia de infraestructura y servicios públicos", en Revista de Derecho administrativo, Círculo de Derecho Administrativo n. ${ }^{\circ}$ 3, 2007, pág. 130 calificándolas de contratos incompletos como consecuencia de la imposibilidad de contemplar ex ante todas las vicisitudes que podrán afectarles durante su larga ejecución. 
a él ni fue considerado discriminatorio. La concesionaria defiende que la razón de interés público ha de responder a circunstancias nuevas, acaecidas con posterioridad, y no a circunstancias preexistentes que no han variado desde entonces y que, en su día, fueron decisivas para otorgarla.

Ante estas posiciones antagónicas, se hace necesario profundizar sobre si concurre la causa para rescatar - la supuesta discriminación-, ponderando la certeza o no de los binomios igualdad/discriminación y gratuidad/peaje.

En relación al binomio igualdad/discriminación-gratuidad/peaje, la existencia de los peajes por sí sola no es discriminatoria. La imposición de un peaje por la utilización de la obra pública no incide, directamente, en los binomios igualdad/discriminación - gratuidad/peaje porque su finalidad no es ni igualar ni discriminar. El peaje persigue, por un lado, contribuir a sufragar los costes de construcción, mantenimiento y explotación de la infraestructura y, por otro, fomentar que se internalicen los costes externos que esa utilización produce a la sociedad, debiendo ser asumidos por los usuarios que, en definitiva, son quienes los generan al utilizarla.

El hecho de que se pague un peaje se debe a la decisión de la Administración Pública de proveer la obra pública mediante el instituto concesional, a cambio de garantizar al concesionario un derecho a la explotación mediante el cobro de un peaje. Esta retribución económica podría haberse decidido que fuera sufragada por la Administración, íntegramente -a través de un "peaje en la sombra" - o por los usuarios. Cuando se opta por lo segundo, como sucede en la concesión del túnel de Sóller, y esta determinación consta en todos los instrumentos jurídicos que rigen la vida de la concesión, Administración debiera respetarla.

Resulta complicado justificar que los municipios afectados puedan invocar, como circunstancia nueva, la existencia de un peaje cuya existencia conocían sobradamente(54) pues fueron consultados sobre este extremo antes de la adjudicación de la concesión, constando este tipo de financiación expresamente en los Pliegos que nunca fueron impugnados, en el Decreto de adjudicación y en el documento de formalización de la concesión, careciendo de argumentos para exigir su supresión más aún cuando reciben bonificaciones de la Administración autonómica que con-

(54) Así consta en las Resoluciones relativas al Anteproyecto del túnel de Sóller, aprobadas en el Pleno del Parlamento, en sesión celebrada día 6 de abril de 1988 (BOCAIB de 14 de abril 1988, n. ${ }^{\circ}$ 23) donde se afirma: «El Pliego de condiciones particulares del Concurso establecerá como uno de los factores de la valoración de las ofertas presentadas, los posibles descuentos que en el peaje puedan gozar los vecinos de Sóller y Fornalutx». 
vierten, prácticamente, en gratuito su paso por la infraestructura del túnel. Existe constancia documental de que los municipios afectados valoraron positivamente la construcción y la explotación del túnel de peaje, en el acta de la Comisión de Gobierno del Ayuntamiento de Sóller (28 de mayo de 1987) donde se afirmaba: "....la Corporación estima que la construcción del túnel que comunique el resto de la Isla con Sóller sin tener que remontar y descender el Coll, beneficia directamente a las localidades de Sóller, Biniaraix, Fornalutx y Puerto de Sóllenn y se concluía que "los beneficios de esta construcción para la Comarca serían considerables obteniendo más ventajas que inconvenientes" y en sentencia del Tribunal Supremo, de 16 de diciembre de 1998, en cuyos antecedentes figura que los municipios conocían los peajes y que mostraron preferencia por las proposiciones que ofertaban peajes más económicos, sin oponerse a los mismos (55).

Consideramos que un peaje no es discriminatorio por el mero hecho de su existencia sino en la medida que su imposición genere desigualdades injustificadas. El carácter discriminatorio de un peaje vendrá de introducir diferencias no objetivas, ni razonables ni justificables entre los usuarios ya que lo que prohíbe el principio de igualdad ante la Ley son las desigualdades que resulten artificiosas o injustificadas por no venir fundadas en criterios objetivos y razonables, según pautas o juicios de valor generalmente aceptados (STC/6/1990, de 26 de abril de 1990). En torno a esta posibilidad, resulta conveniente abordar dos cuestiones relacionadas con el peaje del túnel de Sóller para dilucidar si alguna de ellas evidencia alguna diferencia injustificable que permita tachar el peaje de discriminatorio.

- La posible discriminación por la imposición de distintas clases de tarifas

La legalidad de la existencia de peajes o tarifas especiales y generales que distingue entre usuarios en general y, en concreto, a los del túnel de Sóller fue resuelta por el Tribunal Supremo, en sentencia de 4 julio de 2006 (n. ${ }^{\circ}$ rec. 9890/2003), donde se niega la existencia de discriminación, razonando que las tarifas especiales beneficiosas para determinados usuarios de la vía - los residentes de los municipios más directamente afectados por la construcción de la carretera de peaje- están «justificadas en criterios objetivos y razonables" pues es lógico que quienes con mayor asiduidad utilicen la carretera de peaje, paguen menos que quienes lo hagan de modo esporádico, sobre todo cuando para los primeros ese uso puede constituir una necesidad por razones de residencia, trabajo

(55) Véase en el FJ. VIII de la sentencia cómo los afectados conocían y optaron por las proposiciones más ventajosas en relación a la cuantía del peaje. 
o estudios. La sentencia falla que beneficiar con tarifas más reducidas a quienes están empadronados en los municipios aledaños al túnel no es discriminatorio y está plenamente justificado.

- La posible discriminación por las bonificaciones percibidas por los usuarios de los municipios afectados por el pago del peaje

El Gobierno de las Islas Baleares lleva compensando el gasto que implica el peaje a los usuarios de los municipios afectados por el túnel, para atender este hecho diferencial, con bonificaciones anuales previstas en una serie de Ordenes de las Consellerías competentes, dictadas al amparo del Decreto Legislativo 2/2005, de 28 de diciembre que aprueba el Texto refundido de la Ley de subvenciones, en cuyo artículo 2.3. ${ }^{\circ}$ b) contempla la existencia de bonificaciones "a favor de los usuarios de bienes de dominio público o de servicios públicos aplicables a los precios correspondientes". Bonificaciones cuya finalidad es favorecer la igualdad de quienes se encuentran en una situación objetiva diferencial, en aplicación de un principio de "discriminación positiva" (56).

Estas bonificaciones inicialmente reconocidas a los residentes de Sóller y Fornalutx - únicos municipios contemplados en los Pliegos de la concesión - se ampliaron a los municipios de Escorça y Bunyola (57) por concurrir, también en ellos, circunstancias diferenciadoras objetivas; en caso del municipio de Bunyola fue impulsado por el Defensor del Pueblo (58), al recomendar a la Administración Autonómica la conveniencia de adoptar las medidas precisas para que sus vecinos pudieran hacer uso del túnel de Sóller en idénticas condiciones que los residentes de los municipios de Sóller y Fornalutx, con una bonificación de la tarifa igual para todos, sin excepción. De existir una inicial diferencia de trato entre municipios, ésta desapareció con el referido reconocimiento.

(56) Las consignaciones correspondientes a las bonificaciones del peaje de túnel de Sóller para 2011 fueron de 750, 001,00 €; en 2012: 2.252.195,00€; en 2013: 1.500.000,00€; en 2014: 1.500.000,00€; en 2015: 1.520.967, 94€; en 2016, 1.532.428,43€ y para 2017:1.500.000,00€.

(57) Orden de los Consejeros de Hacienda y Presupuestos y Obras Públicas, Vivienda y Transportes de 11 de octubre de 2002, por la cual se regulan las condiciones para la concesión de una subvención al coste del peaje del túnel de Sóller, a la carretera C-711, para los residentes de los municipios de Sóller i Fornalutx; Orden del Consejero de Presidencia de 21 de febrero de 2003, dictada a propuesta del Consejero de Hacienda y Presupuestos y Obras Públicas, Vivienda y Transportes por la que se regulan las condiciones para la concesión de una subvención al coste del peaje del túnel de Sóller, a la carretera C-711,para los residentes en el municipio de Bunyola que se desplazan al IES Guillem Colom Casanovas de Sóller; Orden del Consejero de Movilidad y Ordenación del Territorio de 26 de mayo de 2009 reguladora de la concesión de una bonificación de tarifas del peaje del túnel de Sóller, a la carretera Ma-11, para los residentes en los municipios de Sóller, Fornalutx, Bunyola y Escorça que deroga las anteriores.

(58) Recomendación 9 de diciembre de 2013 (expediente 11011191). 
Tampoco se aprecia la concurrencia de factores aleatorios objetivos que, al determinar un cambio en la situación inicial de los usuarios, permita inferir la existencia de una desigualdad sobrevenida. Es más, podría pensarse que el descontento de los municipios afectados por el peaje y su pretensión de suprimirlo obedezca a otras circunstancias, ajenas al círculo de la aleatoriedad, como es la dificultad denunciada por los propios usuarios para recibir puntualmente la bonificación a la que tienen derecho. (59)De ser este retraso reiterado, en el cobro de la bonificación, la verdadera causa de la paulatina y creciente percepción negativa de los usuarios en el mantenimiento de la concesión, el rescate no se ajustaría a los condicionantes impuestos por el legislador al no obedecer a una verdadera razón de interés público sino a un incumplimiento imputable a la Comunidad Autónoma Balear. La decisión del Ministerio de Hacienda de imponer la obligación de declarar la bonificación percibida por el peaje en el IRPF, tampoco ayuda; un sinsentido, fruto de un instinto recaudador desmedido (60).

A la vista de lo expuesto faltaría reflexionar sobre el impacto que representa el rescate. Según la Administración Balear, la gratuidad se alcanzaría con la supresión del peaje y pondría fin a la desigualdad, pero debiera demostrarse si iguala, a quiénes lo hace y a costa de qué, pues no queda suficientemente claro. Actualmente, con el peaje pagan los que más utilizan la vía; con la pretendida gratuidad pagaran todos los mallorquines indistintamente - usen o no la vía- porque, al desaparecer la financiación derivada del peaje, su mantenimiento será costeado por todos y al pagar todos, realmente ¿quiénes resultarán beneficiados? Solo quienes utilicen la vía y no residan en las Islas; sin olvidar que el rescate tendrá un coste económico que, también, deberán sufragar los mallorquines.

El Informe del Consejo Consultivo Balear, sin detenerse a comprobar si la discriminación ya existía o si constituye un factor nuevo y sobrevenido que permita justificar el rescate, acepta las razones de la Administración Balear y evita pronunciarse sobre otra cuestión no menos importante: sí rescatar constituye, económicamente, la decisión más ventajosa para los ciudadanos.

(59) En 2011 comenzaron las reclamaciones de las que se hacía eco la Prensa: "Los residentes en Sóller no cobran la subvención para el peaje del túnel desde hace más de 8 meses» https://ultimahora.es/noticias/part-forana/2011/06/04/42288 y a comienzos de este año continua la misma situación. Véase "El PP propone el pago urgente de subvenciones a los residentes de Sóller y Fornalutx» en https://ultimahora.es/noticias/part-forana/2018/01/09/319123.

(60) La fundamentación jurídica se encuentra en el art. 42 1) de la Ley del IRPF de la Ley 35/2006, de 28 de noviembre, donde se dispone: "Constituyen rentas en especie la utilización, consumo u obtención, para fines particulares, de bienes, derechos o servicios de forma gratuita o precio inferior al normal de mercado, aun cuando no supongan un gasto real para quien las conceda" como gastos inherentes a la utilización del vehículo. Resulta criticable, a efectos de tributación, la asociación de rendimientos en especie desconectada de una fuente de renta. 
La Administración Balear debió motivar la resolución del rescate en la conveniencia del cambio de gestión a su favor, desde los parámetros de la sostenibilidad y eficiencia del artículo 85.2 de la Ley 27/2013, de 27 de diciembre, de Racionalización y sostenibilidad de la Administración Local aplicable, pese a ser posterior a la fecha en se adjudicó y novó la concesión, por afectar al procedimiento y a la motivación de la resolución que sí se regulan por la legislación vigente en el momento de decidir el rescate. Dado que este precepto incorpora unos criterios dirigidos a reducir la discrecionalidad para elegir entre los distintos modos de gestión y que son "presupuesto de la organización y gestión de los servicios locales»(61), creemos que la decisión de rescatar refuerza todavía más la necesidad de motivación porque comporta un cambio a la gestión directa que no constituye la opción preferida por el legislador.

Esta parte de la motivación, olvidada por la Administración Balear, no es advertida por el Consejo Consultivo de las Islas Baleares emitiendo un juicio favorable a una motivación incompleta. Desde estas consideraciones, la decisión de rescatar debió pararse a argumentar la conveniencia del cambio de gestión desde los parámetros de la sostenibilidad y la eficiencia.

\subsubsection{La valoración económica del rescate}

La Administración Balear y el concesionario se enfrentan por discrepar no solo sobre la legalidad del rescate sino también sobre el montante económico del mismo, cuya diferencia es muy significativa. Para el Consejo Insular el rescate asciende a la cifra de 15.442.849, 39 euros y para la concesionaria a 30.968 .000 euros, prácticamente el doble. Sin perjuicio de esta importante diferencia en el importe de la indemnización que habrán de dirimir los Tribunales al resolver el recurso presentado por la concesionaria, es necesario reflexionar sobre las partidas indemnizables y los criterios empleados para determinar su valor, sin olvidar una peculiaridad de este caso particular.

Las partidas que integran el importe económico del rescate son:

(61) VILLAR ROJAS (Op. cit., págs. 96 a 106) entiende que el precepto «da paso a la aplicación de reglas determinadas por la Ley: preferencia implícita por la gestión indirecta (mediante contrato) y por la financiación por los usuarios (tasas, tarifas); y, en su defecto, por la gestión directa administrativa, también con tasas y tarifas. La gestión directa empresarial aparece como una excepción que requiere de especial justificación" y (...) en los procesos de remunicipalización "su puesta en marcha requiere, con carácter previo, superar el filtro de las reglas sobre sostenibilidad financiera y estabilidad presupuestaria, sólo entonces aquél será viable. Pero, además, de superar esas exigencias, la decisión local sobre la forma de gestión queda condicionada por las preferencias establecidas por el legislador de régimen local, que se basan en aquellos mismos principios.» 
-El coste derivado de la indemnización al concesionario. La cuantía de la indemnización se integra por el importe del valor de las obras e instalaciones de la concesión, por el lucro cesante y por los daños y perjuicios irrogados al concesionario.

Obras e instalaciones de la concesión. Entre las obras e instalaciones de la concesión a transferir, para poder continuar con la explotación tras el rescate, se hace necesario distinguir entre las que no hubieran revertido a la Administración al finalizar el término de la concesión y las que sí lo hubieran hecho.

En relación a las primeras, la Administración pública debe abonar el precio de las obras e instalaciones que el concesionario haya ejecutado, valorándose en atención a su estado actual y al tiempo que faltaría para la reversión de haber llegado la concesión a término final. Para calcular su valor se atiende al criterio de la depreciación experimentada.

En relación a las segundas, la Administración pública debe abonar el precio de las obras e instalaciones recibidas, valorándose la inversión neta realizada tras restarle la amortización acumulada, el fondo de reversión (62) y otros conceptos (por ejemplo, las subvenciones de capital). En definitiva, se busca compensar al concesionario por la inversión realizada no recuperable con la explotación, al haberse anticipado su fin con el rescate.

Lucro cesante. Se indemniza al concesionario por los beneficios dejados de percibir. Según la legislación aplicable, los beneficios dejados de percibir se calcularán atendiendo a dos elementos: a los resultados de explotación del último quinquenio, que figuran en la cuenta de resultados (pérdidas y ganancias) de la concesión rescatada, y a la pérdida de valor de los activos que no revertirán en la Administración por el cese anticipado de la explotación. El cálculo recae sobre beneficios brutos, excluyéndose el pago de impuestos para evitar una doble tributación.

Como viene señalando la jurisprudencia(63), el lucro cesante deberá ser probado de manera que incluya los beneficios ciertos, concretos y acreditados que debía haber percibido el perjudicado y excluya los beneficios hipotéticos, imaginarios o meros sueños de fortuna. Los criterios para determinar el valor del daño deben fundamentarse en elementos objetivos y razonables y no en un cálculo abstracto o estimativo de las pérdidas experimentadas. Estos elementos sobre los

(62) Es un valor neto contable estimado de los activos a revertir en el momento de la reversión más los gastos necesarios. Se realizará a través de un plan sistemático vinculado al periodo de vigencia de la concesión y la cuota anual se calculará en razón de los ingresos que, de futuro, se prevean obtener.

(63) Sentencia delTribunal Supremo de 5 de noviembre de 1998, RJ 199818404. 
que se fundamenta la valoración deben buscarse en la documentación contractual, debiéndose estar a lo previsto en los Pliegos. Cuando, por discrepancia entre las partes, la fijación del lucro cesante deba ser decidida por los Tribunales, éstos deben procurar un equilibrio que huya tanto del rechazo de lucro cesante por entender que tiene carácter hipotético, como de su admisión incondicional sin prueba alguna (STS de 9 de abril de 2012, RJ 2012l8986).

Otros daños y perjuicios. Engloba pérdidas por conceptos menos homogéneos que no figuren en las partidas anteriores y que el concesionario deberá probar. Destaca, por un lado, el coste derivado de gastos por operaciones financieras contraídas por el concesionario que éste se ve obligado a rescindir y, por otro, el coste de los gastos por despido del personal, cuando la Administración no quiera mantener los puestos de trabajo; su pérdida exige la cuantificación de las indemnizaciones del personal, así como las cantidades destinadas a atender los subsidios de desempleo.

-El coste representado por los impuestos a que está sujeta la concesión y las operaciones relativas a su explotación.

-El coste derivado del mantenimiento y conservación de la infraestructura rescatada que deberán asumirse por la Administración que pasa a gestionarla directamente (64).

El dictamen del Consejo Consultivo de Baleares, cuando valora las distintas partidas que integran el importe de la indemnización del concesionario no razona -o lo hace insuficientemente - sobre la corrección de los criterios utilizados por la Administración para calcular su importe y elude pronunciarse sobre otras partidas que, aunque ajenas a la indemnización del concesionario, también repercuten en el coste final del rescate.

a. La necesidad de una mayor seguridad jurídica en los criterios utilizados para concretar los elementos indemnizables

Los criterios controvertidos afectan al:

- Cálculo de la depreciación. La ausencia de un criterio específico en la Ley o en los Pliegos, para evaluar la depreciación de las obras e

(64) El mantenimiento del túnel de Sóller costará cada año, según informaciones contradictorias, entre 600.000 y 834.000 euros. El coste, no lo asumirá el Consejo Insular hasta el año 2023, porque durante los primeros cinco años se pagará con la aportación que hará el Gobierno para la recuperación de la concesión (4,1 millones de euros).Véase http://www.diariodemallorca.es/ mallorca/2017/07/15/ y https://www.arabalears.cat/balears/ 07/02/2017. 
instalaciones, posibilita a las partes optar entre dos criterios diferentes: el criterio de amortización lineal (cada año se amortiza el mismo importe, dividiendo la inversión total por los años que dura la concesión) y el criterio de amortización por uso (cargando una parte más grande de la amortización en aquellos años donde se prevé que habrá más tránsito y se generaran más ingresos). De estos criterios, la Administración elige el primero. Optar por un criterio $u$ otro no es indiferente y altera el montante del importe de esta partida por lo que debiera haberse explicado.

- Cálculo del lucro cesante. Su cuantificación puede hacerse atendiendo a los beneficios históricos o en función de los beneficios esperados en el Plan económico-financiero. En ausencia de un criterio específico en los Pliegos o en la Ley, la Administración opta por el criterio de los beneficios históricos al considerar que las previsiones del Plan económico-financiero, sobre las que el concesionario efectúa el cálculo, constituyen meras expectativas o conjeturas. Como probablemente en esta partida radica la mayor diferencia en el cálculo efectuado por la Administración y la concesionaria, creemos que merecía un razonamiento mucho más detallado.

- Tasa de actualización(65). Esta puede basarse en un criterio de mercado o en el coste legal del dinero. Optar por uno u otro criterio tampoco es indiferente, arrojando un saldo ventajoso para la Administración o para el concesionario según cuál sea el criterio elegido y el periodo de tiempo de explotación de la concesión cuantificado a través del mismo. La Administración elige la tasa de actualización de mercado por considerarla más apropiada para un contrato de larga duración y porque representa la opción más económica para ella.

-El coste de los impuestos. El Consejo Consultivo da la razón a la concesionaria al reclamar una indemnización por los gastos que habrá de soportar respecto al pago del IBI de 2017 y a la regularización de las deducciones del impuesto del IVA correspondiente a algunos ejercicios anteriores por la adquisición de bienes o la realización de obras de mejora efectuadas en el túnel. El Consejo Consultivo recomienda a la Administración revisar el importe final del rescate, teniendo en cuenta el coste de esta partida que no aparece valorada cuando calcula la cuantía del rescate.

- La indemnización por despido. El Consejo Consultivo y el Consejo Insular de Mallorca discrepan en este punto y no aluden a las con-

(65) Factor financiero utilizado para determinar el valor del dinero en el tiempo y así calcular el valor actual de un capital futuro. 
secuencias derivadas de la subrogación o no de los trabajadores. Mientras que el Consejo Consultivo es contrario a la subrogación por el Consejo Insular de Mallorca del personal de la empresa concesionaria, lo que implica la extinción de estos puestos de trabajo con un coste importante que no se detiene a valorar, el Consejo Insular de Mallorca es partidario de la subrogación, distinguiendo entre el personal de la concesionaria del que se hace responsable, a todos los efectos, la empresa encargada del contrato para el mantenimiento de los túneles de Sóller y Sa Mola y otros dos ingenieros que pasan a formar parte del personal del Consejo Insular de Mallorca, subrogándose en los derechos y obligaciones laborales y de la Seguridad Social correspondientes a aquéllos. La doctrina (66) y la jurisprudencia (67) tampoco son unánimes, existiendo ambigüedad sobre si la asunción de la gestión por la Administración de una actividad prestada en régimen de concesión acarrea o no la asunción del personal que hasta ese momento venía prestando la actividad. El Tribunal Supremo afirma que la solución debe buscarse en los Pliegos que debieran prever esta circunstancia, dándoles prioridad incluso en contra del mandato imperativo de la norma (68).

Las discrepancias expuestas que enfrentan a la Administración y a la concesionaria en los criterios elegidos para cuantificar las partidas indem-

(66) Véase sobre esta problemática a ALFONSO MELLADO. CL., "La reversión a la gestión directa de servicios públicos: problemas laborales», en El Cronista del Estado Social y Democrático de Derecho $n .^{\circ} 69$, lustel, 2017.

(67) En este sentido, las consideraciones de SAN MARTÍN AGUILAR a la sentencia del Tribunal Supremo de 5 de abril de 1993 en "Aspectos laborales del cambio de titularidad en los supuestos de rescate de concesiones administrativas y de sucesión de contratas," $T L . \mathrm{n} .{ }^{\circ} 43,1997$, pág. 75 y ss.

(68) Véase el artículo 44 del Estatuto de los Trabajadores. La Disposición adicional vigésima sexta de la Ley 3/2017 de Presupuestos Generales para 2017, en la Disp. Adicional n. ${ }^{\circ} 26$ señala: Uno. Con efectos desde la entrada en vigor de esta Ley y vigencia indefinida, las Administraciones Públicas del artículo 2 del texto refundido de la Ley del Estatuto Básico del Empleado Público, aprobado por el Real Decreto Legislativo 5/2015, de 30 de octubre, no podrán considerar como empleados públicos de su artículo 8, ni podrán incorporar en dicha condición en una Administración Pública o en una entidad de derecho público: a) A los trabajadores de los contratistas de concesiones de obras o de servicios públicos o de cualquier otro contrato adjudicado por las Administraciones Públicas previstas en el artículo 2.3 de la Ley 40/2015, de 1 de octubre, de Régimen Jurídico del Sector Público, cuando los contratos se extingan por su cumplimiento, por resolución, incluido el rescate, o si se adopta el secuestro o intervención del servicio conforme a la legislación de contratos del sector público que resultase aplicable a los mismos. b) Al personal laboral que preste servicios en sociedades mercantiles públicas, fundaciones del sector público, consorcios, en personas jurídicas societarias o fundacionales que vayan a integrarse en una Administración Pública. Al personal referido en los apartados anteriores le serán de aplicación las previsiones sobre sucesión de empresas contenidas en la normativa laboral». 
nizables evidencian una falta de seguridad jurídica a la hora de fijar el coste económico de un rescate. Se echa en falta, en el Ordenamiento jurídico, la previsión de unos criterios claros que proporcionen un método capaz de fijar, con la mayor exactitud posible, el importe del coste real de un rescate. Un cálculo fiable es muy importante en la medida que atañe a partidas que ascienden a cuantías considerables que, a la postre, habrán de sufragarse con el dinero de los ciudadanos. La Administración está obligada a responder de las decisiones que comprometen el gasto público por respeto a los principios de «buena administración» y de «transparencia».

\section{b. Del periodo temporal sobre el que versa la indemnización por rescate}

Las distintas partidas que integran la indemnización se calcularan por el periodo que va desde la fecha del rescate, que determina la extinción de la relación, hasta la fecha prevista de vencimiento de la concesión cuya explotación cesa anticipadamente por el rescate. Para calcular el importe final, relativo a ese periodo, se estará a las previsiones del Plan económico-financiero del año 2007 con un límite infranqueable, en este caso particular. Dado que la prórroga de la concesión del túnel de Sóller hasta el año 2022 y el Plan económico-financiero (periodo 2007-2022) constituyen una modalidad de cumplimiento del fallo de las sentencias del Tribunal Superior de Baleares de 19 de abril de 2004 y de 12 de marzo 2004 a la indemnización por valor de 7,4 millones de euros reconocida al concesionario, el importe de esta cantidad actuara de mínimo necesario e irreducible del total indemnizatorio.

La empresa concesionaria podría haber argumentado que la Administración, con el rescate, pretendía eludir el cumplimiento del fallo de una sentencia firme lo que le hubiera permitido solicitar su anulación en vía de incidente de ejecución de sentencia, evitando su materialización en lugar de haberlo impedido con la solicitud de una medida cautelar de suspensión - como ha sucedido en la realidad - con un resultado más contundente: impedir el ejercicio de la potestad de rescate $y$, en caso de actuarla, que dicha actuación pueda ser constitutiva de ilegalidad por desviación de poder(69).

(69) El Tribunal Supremo, en sentencias de 29 de abril de 2009 (RJ 200915146) y 23 de octubre de 2009 (RJ 2010\1198) opta invertir la carga de la prueba respecto a la presunción de legalidad de los actos administrativos y exigir que sea la Administración la que acredite o argumente que el acto o disposición no tienen por finalidad eludir el cumplimiento de las sentencias. 
c. De la normativa aplicable para calcular el importe de la indemnización por rescate

En este caso, para delimitar el importe de la indemnización del concesionario hay que estar a los términos de la ley del contrato - sus Pliegos y el decreto de adjudicación de la concesión- y a la normativa vigente en aquel momento, salvo en lo relativo a las estipulaciones de carácter económico que se rigen por el Plan económico-financiero de 2007, consecuencia de la novación modificativa de la concesión originaria que determinó una prórroga de su duración y el ajuste de las condiciones económico-financieras a este nuevo periodo temporal.

\section{Redefiniendo el rescate. Propuestas de mejora}

La Administración Pública, aunque confíe a un particular la construcción y explotación de la obra pública de un túnel, continúa ostentando sobre la concesión un conjunto de potestades administrativas de ejercicio unilateral. Esto pasa porque la titularidad de la actividad sigue perteneciéndole en base a las competencias que el legislador le atribuye en materia de comunicaciones, de obras públicas y sobre los bienes demaniales en donde se sitúa la infraestructura y porque la actividad, pese a ser desarrollada por el concesionario, no pierde su carácter público en la medida que garantiza la prestación de un servicio, el tránsito de personas y mercancías.

Las distintas potestades administrativas reconocidas a la Administración por el legislador durante la vigencia de la relación contractual persiguen proteger, de manera diferente, el interés público implícito en ella bajo el prisma de que es Administración quien lo representa, personaliza y garantiza.

Pero la intensidad del interés público comprometido no es igual en todos los contratos en los que la Administración interviene ni siempre está representado por ella en exclusiva. Concretamente, en una concesión de obras, los afectados por la vida y vicisitudes de la relación concesional y por el interés público implícito en ella, no son únicamente el concedente $y$, de alguna forma, el concesionario sino también los usuarios y la colectividad en general ya que la concesión existe en función y en beneficio de un interés público que los incluye a todos (70).

(70) CARREAU, (Concessionaire de service public: el travaux realises sur le domaine public, AJDA, París, 1966, pág. 81) alude a los fines implícitos en la concesión administrativa, y entiende que "en la concesión administrativa se ha encontrado una razonable fórmula que equilibra, sin menoscabo alguno de una lógica y obligada planificación, la actividad individual competitiva y con suficiente margen de creatividad, y las necesidades comunitarias". 
Dado que la Ley 9/2017de Contratos del Sector Público, de 8 de noviembre, admite el rescate como una forma de resolución de la concesión, como ocurría en la legislación anterior, pudiera pensarse que no ha habido cambios pero, lo cierto, es que esta norma ha operado una transformación en su regulación y, con ello, en la concepción originaria de la potestad de rescate. Esta transformación deriva de que el interés público, causa legitimadora del rescate, no puede continuar siendo fruto de una percepción reducida y empobrecedora del mismo que relegue los intereses del concesionario (71), de los usuarios $y$, especialmente, los de la colectividad.

La potestad administrativa de rescate no va a poder ejercitarse sólo porque la Administración afirme la existencia de un determinado interés público sino porque constituya el medio necesario para que, en adelante, la actividad prestada continúe siendo beneficiosa para el conjunto (72).

Desde estas consideraciones, el rescate deberá ajustarse a las siguientes premisas:

Primera, no podrá articularse como una potestad incondicionada porque, de ser así, se convertiría en un grave inconveniente para potenciales concesionarios ante proyectos poco seguros para la estabilidad de sus inversiones, minando con ello su interés y afectando negativamente al instituto de la concesión como modalidad de colaboración pública-privada.

Segunda, deberá repercutir beneficiosamente en los usuarios o, mínimamente, no perjudicarles. En este sentido, la Administración pública debe razonar la conveniencia de que ella asuma la actividad en lugar de continuar haciéndolo el concesionario, garantizándoles que será una gestión eficiente y que no les causará inconvenientes.

Tercera, sólo procederá si constituye la opción más conveniente desde los principios de sostenibilidad y eficiencia, impuestos por la Ley, tras comparar el coste de rescatar y el coste de no hacerlo dado que el rescate compromete el gasto público y termina siendo financiado por los admi-

(71) El administrado que colabora con la Administración puede perseguir fines diversos, pero no opuestos y esto es así porque "el fin privado coadyuva con el público». Véase a DE CORES. C y CAL. J.A. «El concepto de interés público y su incidencia en la contratación administrativa», en Revista de Derecho de Montevideo, n. ${ }^{\circ} 11,2007$, pág. 136.

(72) En este sentido, SÁINZ MORENO. F., "Sobre el interés público y la legalidad administrativa», en $R A P \mathrm{n} . .^{\circ} 82$, págs. 444-5) distingue entre la apreciación abstracta del interés general que toma en consideración un tipo de actividad, de operación, de decisión, sin considerar las circunstancias específicas del caso y la apreciación concreta que valora si la actividad, operación o decisión responde a un interés general definido precisamente en consideración a hechos específicos. Las consecuencias de una y otra apreciación son distintas. En caso de litigio la apreciación concreta conduce a un control más profundo que la apreciación abstracta. 
nistrados. Se impone, por esta razón, un ejercicio transparente de la referida potestad.

Cuando la Administración precise ejercitar la potestad de rescate para proteger un concreto interés público, está obligada a hacerlo de manera proporcionada tras una valoración ponderada de todos los factores que concurren en la satisfacción de ese interés. En definitiva, ese ejercicio habrá de ser excepcional, prudente y razonado. Cualquier operador jurídico debe desterrar la posibilidad de una configuración implícita de la misma y debe respaldar una interpretación restrictiva a la hora de legitimar su utilización (73).

Trabajo recibido el 2 de febrero de 2018

Aceptado por el Consejo de Redacción el 16 de febrero de 2018

(73) CASSAGNE. JC., («Evolución de los principios aplicables a los servicios públicos y problemas actuales tras los procesos de privatización", en $R A P$ n. ${ }^{\circ} 157,2002$, pág.479) en este sentido, se manifiesta a favor de mecanismos que tiendan a fortalecer la estabilidad de las concesiones, como la interdicción del rescate y la revocación por oportunidad, sobre cuya inconveniencia comienza a forjarse consenso, al menos para no aceptar su configuración implícita. 
LABURPENA: Administrazioaren erreskate-ahalak bilakaera eduki du. Kontzepzio tradizionaletik abiatu da, non interes publikoa -Administrazioak bakarrik ordezkatua - nahikoa zen administrazio-emakida bati aurretik amaiera emateko, eta interes publikoaren gaineko pertzepzio integratzailea ezartzen duen kontzepzio eguneratu batera iritsi da, non harremanean eragindakoen interesak behar bezala dauden baloratuta, guztiek laguntzen baitiote emakidan dagoen interes publiko inplizituari. Beraz, multzoarentzat etekina ekartzen duenean bakarrik erabil daiteke erreskate-ahala. Erreskate-ahala erabiltzeko, interes publikoa dagoela erakutsi behar da, eta interes publiko horrek justifikatu egin behar du ordura arte emakidadunak egin duen jardueraz bestelako kudeaketa-modua behar dela (hortik aurrera, Administrazioaren esku geratzen da). Kudeaketa-modua aldatzea komeni delako justifikazioa aztertu egin behar da, jasangarritasun- eta efizientziaprintzipioetatik begiratuta, eta argi geratu behar da, administrazio-gardentasuna aplikatuz, erreskatea dela aukera onena.

GAKO HITZAK: Sóller. Erreskatea. Obra publikoak. Motibazioa. Kostua.

RESUMEN: La potestad administrativa de rescate ha evolucionado desde una concepción tradicional donde el interés público, representado en exclusiva por la Administración, resultaba suficiente como causa legitimadora para poner fin anticipadamente a la concesión administrativa a una concepción actualizada que impone una percepción integradora del interés público en la que, los intereses de los distintos afectados en la relación, estén convenientemente valorados pues todos coadyuvan al interés público implícito en la concesión, de manera que la potestad de rescate sólo pueda actuarse cuando arroje un saldo beneficioso para el conjunto. El ejercicio de esta potestad de rescate exige la demostración de un interés público sobrevenido que justifique un modo de gestión diferente de la actividad prestada hasta el momento por el concesionario y que, en adelante, queda en manos de la Administración. La justificación de la conveniencia del cambio de gestión deberá ser analizada desde los principios de sostenibilidad y eficiencia quedando meridianamente claro, en un ejercicio de transparencia administrativa, que rescatar es la opción óptima.

PALABRAS CLAVE: Sóller. Rescate. Obra pública. Motivación. Coste.

ABSTRACT: The Administration power of bailout has evolved from a traditional conception where public interest, represented exclusively by the Administration, was enough as a legitimating cause to put an anticipated end to an administrative concession, to an updated conception imposing an integrating perception of public interest where the interests of the different stakeholders are suitably valued because they all contribute to the public interest implicit in the concession, so that the bailout power can only be used when it yields a balance beneficial to the whole. The exercise of this bailout power requires to demonstrate an unforeseen public interest justifying a change of management of the activity provided so far by the concessionaire and that will stay onwards in the hands of the 
Administration. The justification of the convenience of the change in management should be analyzed from the principles of sustainability and efficiency, being very clear, through an administrative transparency exercise, that the bailout is the optimal option.

KEYWORDS: Sóller. Bailout. Public works. Motivation. Cost. 